\title{
Forebrain-Specific Glutamate Receptor B Deletion Impairs Spatial Memory But Not Hippocampal Field Long-Term Potentiation
}

\author{
Derya R. Shimshek, ${ }^{1}$ Vidar Jensen, ${ }^{3}$ Tansu Celikel, ${ }^{2}$ Yu Geng, ${ }^{1}$ Bettina Schupp, ${ }^{1}$ Thorsten Bus, ${ }^{1}$ Volker Mack, \\ Verena Marx, ${ }^{1}$ Øivind Hvalby, ${ }^{3}$ Peter H. Seeburg, ${ }^{1}$ and Rolf Sprengel ${ }^{1}$ \\ Departments of ${ }^{1}$ Molecular Neurobiology and ${ }^{2}$ Cell Physiology, Max Planck Institute for Medical Research, D-69120 Heidelberg, Germany, and ${ }^{3}$ Molecular \\ Neurobiology Research Group, Institute of Basic Medical Sciences, University of Oslo, N-0317 Oslo, Norway
}

We demonstrate the fundamental importance of glutamate receptor B (GluR-B) containing AMPA receptors in hippocampal function by analyzing mice with conditional GluR-B deficiency in postnatal forebrain principal neurons $\left(G l u R-B^{\Delta F b}\right)$. These mice are as adults sufficiently robust to permit comparative cellular, physiological, and behavioral studies. GluR-B loss induced moderate long-term changes in the hippocampus of GluR-B ${ }^{\Delta F b}$ mice. Parvalbumin-expressing interneurons in the dentate gyrus and the pyramidal cells in CA3 were decreased in number, and neurogenesis in the subgranular zone was diminished. Excitatory synaptic CA3-to-CA1 transmission was reduced, although synaptic excitability, as quantified by the lowered threshold for population spike initiation, was increased compared with control mice. These changes did not alter CA3-to-CA1 long-term potentiation (LTP), which in magnitude was similar to LTP in control mice. The altered hippocampal circuitry, however, affected spatial learning in $G l u R-B^{\Delta F b}$ mice. The primary source for the observed changes is most likely the AMPA receptor-mediated $\mathrm{Ca}^{2+}$ signaling that appears after GluR-B depletion, because we observed similar alterations in $G l u R-B^{Q F b}$ mice in which the expression of $\mathrm{Ca}^{2+}$-permeable AMPA receptors in principal neurons was induced by postnatal activation of a Q/R-site editing-deficient GluR-B allele.

Key words: conditional knock-out; GluR-B; AMPA receptors; LTP; learning and memory; Co $^{2+}$ uptake; T-maze

\section{Introduction}

In the CNS, AMPA receptors are the key elements of fast synaptic transmission. AMPA receptors are heteromeric or homomeric ion channel assemblies based on four subunits, glutamate receptor A (GluR-A), GluR-B, GluR-C, and GluR-D (Keinanen et al., 1990) (GluR1-GluR4). Heteromeric GluR-A/-B and GluR-B/-C assemblies constitute the AMPA receptor pools in hippocampal principal cells (Wenthold et al., 1996). GluR-B/-C heteromers are a part of a "constitutive receptor pool," whereas GluR-A/-B heteromers provide a "reserve pool" operating through a "facultative transport pathway" during activity-induced enhancement of synaptic transmission at hippocampal pyramidal cells (Shi et al., 1999, 2001). This model is supported by GluR-A-deficient mice, which have a depleted CA1 "AMPA receptors reserve pool" ( $\mathrm{Za}-$ manillo et al., 1999; Andrásfalvy et al., 2003), impaired hippocampal synaptic plasticity, and impaired working memory

Received Dec. 19, 2005; revised June 26, 2006; accepted June 26, 2006.

We thank Dr. G. Schütz for mouse lines and A. Herold, J. Kern, L. Pan, and M. Lang for technical assistance.

Correspondence should be addressed to Rolf Sprengel, Max Planck Institute for Medical Research, Jahnstrasse 29,

D-69120 Heidelberg, Germany. E-mail: sprengel@mpimf-heidelberg.mpg.de.

Y. Geng's present address: Sir Run Run Shaw Hospital, Zhejiang University, Hangzhou 310016, China.

B. Schupp's present address: Actelion Pharmaceuticals Deutschland, D-79111 Freiburg, Germany.

V. Mack's present address: Department of Clinical Neurobiology, University of Heidelberg, D-69120 Heidelberg, Germany.

D. R. Shimshek's present address: Novartis, $\mathrm{CH}-4002$ Basel, Switzerland. DOI:10.1523/JNEUROSCI.5410-05.2006

Copyright $\odot 2006$ Society for Neuroscience $\quad 0270-6474 / 06 / 268428-13 \$ 15.00 / 0$
(Mack et al., 2001; Reisel et al., 2002). However, in contrast to the model, GluR-C knock-out mice showed that AMPA receptor mediated CA3-to-CA1 synaptic transmission and hippocampal learning are unaffected by loss of GluR-C (Borchardt, 2002; Meng et al., 2003; Sanchis-Segura et al., 2006). These results suggest that GluR-A/-B receptors constitute the main AMPA receptor pool in CA1 pyramidal cells, and that GluR-A/-B receptors may participate also in the "constitutive transport pathway."

For AMPA receptor delivery and recycling at the constitutive receptor pool of hippocampal pyramidal cells, the GluR-B subunit is necessary (Shi et al., 2001). The lack of GluR-B leads to a significant reduction of synaptic AMPA currents (Jia et al., 1996). The remaining GluR-A and GluR-C homomers or GluR-A/-C heteromers (Sans et al., 2003) are sensitive to voltage-dependent polyamine block, exhibit increased single-channel conductance, and are $\mathrm{Ca}^{2+}$ permeable (Jia et al., 1996). This AMPA receptormediated $\mathrm{Ca}^{2+}$ entry can lead to neuronal cell death when induced by either kainic acid-mediated status epilepticus or transient forebrain ischemia (Pollard et al., 1993; Friedman, 1998; Friedman and Koudinov, 1999; Grooms et al., 2000).

The primary importance of GluR-B is documented by the phenotypic behavior of GluR-A, GluR-B, and GluR-C knock-out mice. $G l u R-B$ knock-out mice are hypomorphs with runted appearance, have poor motor coordination, display low explorative activity, and are incapable of breeding (Jia et al., 1996, 2001; Shimshek et al., 2006). GluR-A and GluR-C knock-outs, con- 
versely, exhibit a phenotype not very different from wild type (Meng et al., 2003; Bannerman et al., 2004; Sanchis-Segura et al., 2006).

To unmask the role of GluR-B in neuronal plasticity and behavior of adult mice, we restricted GluR-B gene inactivation to principal neurons in the postnatal forebrain. These mice, termed $G l u R-B^{\Delta F b}$, appeared robust in adulthood and permitted cellular and behavioral experiments to be performed. We also used GluR$B^{Q F b}$ mice (Krestel et al., 2004), characterized by an atypical AMPA receptor population, of which $\sim 25 \%$ consist of $\mathrm{Ca}^{2+}$. permeable AMPA receptors caused by Q/R-site unedited GluR$\mathrm{B}(\mathrm{Q})$ (Brusa et al., 1995). We could thus visualize the cellular and synaptic consequences of AMPA receptor-mediated $\mathrm{Ca}^{2+}$ influx in two different genotypes. GluR-B $B^{Q F b}$ mice had a shorter lifespan and differ in their life expectancy because of recurrent seizures (Krestel et al., 2004) that precluded long-term behavioral analysis.

\section{Materials and Methods}

Mice and genotyping. Animal housing were performed according to the institutional guidelines at the animal facility of the University of Heidelberg. Animal experiments were registered in the Regierungspräsidien Karlsruhe and Tübingen (37-9185.81/35/97, 35-9185.82/131/01, 359185.81/G-115/04, and 359185.81/G-10/02).

Gene-targeted mice ( $\left.G l u R-B^{2 l o x}\right)$ with loxP sites flanking GluR-B gene (Gria2) exon 11 were generated by embryonic stem (ES) cell gene targeting. The vector for GluR-B gene targeting was modified from a genetargeting vector used previously (Kask et al., 1998) that contained 129/Sv mouse genomic DNA covering exons $10-12$ of the GluR-B gene. A third loxP element with the same orientation as the previously introduced loxP sites was inserted into intron 10 between two BbsI restriction sites whereby an NsiI restriction site was removed. The SacI linearized targeting vector pGRBR-cKO was electroporated (gene pulser, $240 \mathrm{~V}$ and 500 $\mathrm{mF}, 107$ cells; Bio-Rad, Hercules, CA) into mouse R1 ES cells as described previously (Nagy et al., 1993), and G418 resistant cells (250 mg/ml G418) were screened for homologous recombination by nested PCR with primers rsp27/pgk-Prom1 and rsp28/pgk-Prom2 verified via a diagnostic digest using NsiI and a sequencing reaction using primers VM-17 und VM-18. Successful targeting was finally confirmed by Southern Blot analysis with the B-5' outside probe. The PGKneo gene was removed by electroporation of the recombinant ES cells with a green fluorescent protein-Cre recombinase encoding plasmid pBS-500 (Gagneten et al., 1997), and removal was verified by PCR with primers VM-10 and VM17. Primer sequences are as follows: rsp27, AGA TGA GGA GTC ATG CCT AAC; pgk-Prom1, GAA TGT GTG CGA GGC CAG AGG; pgkProm2, CAG ACT GCC TTG GGA AAA GCG; VM-10, GTT GTC TAA CAA GTT GTT GAC C; VM-17, GAA TCA TTG TTG ACA ATT GCC AC; and VM-18, CTT GGA ATG GAA GGA GAT GG. Successful homologous recombination and PGKneo gene removal was further verified via Southern blot analysis using three independent probes termed B-5' inside, B-3' inside, and neo probe (supplemental Fig. 1, available at www. jneurosci.org as supplemental material). Successfully targeted ES cells were injected into mouse blastocysts (C57BL/6), and the resulting chimeric animals were bred with $\mathrm{C} 57 \mathrm{BL} / 6$ mice, finally leading to positive heterozygous offspring containing a GluR-B ${ }^{2 l o x}$ allele.

GluR-B ${ }^{\Delta F b}$ mice (Shimshek et al., 2005) are homozygous for the floxed GluR-B allele (GluR-B $B^{2 l o x / 2 l o x}$ ) (Shimshek et al., 2005) and positive for transgenic $\mathrm{Tg}^{\mathrm{Cre} 4}$. Littermates without $\mathrm{Tg}^{\mathrm{Cre} 4}$ were named herein as controls. GluR-B ${ }^{Q F b}$ mice, also named GluR-B $B^{\Delta E C S . F b}$ (Shimshek et al., 2005), are heterozygous for $\mathrm{Tg}^{\mathrm{Cre} 4}$ and heterozygous for the floxed TKneo cassette in the GluR-B allele $\left(G l u R-B^{+/ n e o}\right)$. GluR-B knock-out mice were generated by breeding GluR-B $B^{2 l o x / 2 l o x}$ with Cre-deleter mice (Schwenk et al., 1995). Mice were genotyped by tail PCR with specific primers. Given are the primer sequences and the approximate lengths of the amplified DNA fragments: $\mathrm{Tg}^{\mathrm{Cre} 4}$ and Cre-deleter, rspCre1 (5'-ACC AGG TTC GTT CAC TCA TGG-3') and rspCre2 (5'-AGG CTA AGT GCC TTC TCT ACAC-3'), 200 bp; GluR- ${ }^{+/ n e o}$, MH60 (5' -CAC TCA
CAG CAA TGA AGC AGG AC-3'), MH53a (5'-GAA TGT TGA TCA TGT GTT TCC CTG-3'), and MH117 (5'-GTT CGA ATT CGC CAA TGA CAA GAC G-3'), 500 bp for wild-type and 400 bp for mutant; GluR- $B^{2 l o x}$, VM-12 (5'-GCG TAA GCC TGT GAA ATA CCT G-3') and VM-10 (5'-GTT GTC TAA CAA GTT GTT GAC C-3'), 250 bp for wild type and $350 \mathrm{bp}$ for mutant. Unless otherwise mentioned, genemanipulated mice and littermate controls were older than 2 months [older than postnatal day 60 (P60)]. Males and females were used for the experiments.

Histochemistry. For immunohistochemistry, coronal or sagittal 70- to $100-\mu \mathrm{m}$-thick vibratome slices, $15-\mu \mathrm{m}$-thick sagittal cryostat slices, or 5 - $\mu$ m-thick sagittal paraffin slices were used as described previously (Shimshek et al., 2002) with different primary antibodies [antiparvalbumin (monoclonal, 1:1000; Sigma, Taufkirchen, Germany), anti-somatostatin (monoclonal, 1:400; Chemicon, Hampshire, UK), anti-bromodeoxyuridine (BrdU) (monoclonal, 1:100; Accurate Chemicals, Westbury, NY), and anti-Ki67 (monoclonal, 1:50; Novo Castra, Newcastle, UK)]. Secondary anti-mouse, anti-rabbit, and anti-rat antibodies coupled to horseradish peroxidase and biotinylated secondary antibodies (each 1:600) and ABC kit were used (Vector Laboratories, Peterborough, UK). Slices were stained with 3-3' diaminobenzidine (DAB) (Sigma), mounted on slides, and air dried. DAB-developed slices were coverslipped with eu-kitt (O. Kindler, Freiburg, Germany) and analyzed with a Axiovert 100 Zeiss (Göttingen, Germany) microscope. For immunofluorescence, primary anti-neuronal-specific nuclear protein (NeuN) (monoclonal, 1:1000; DakoCytomation, Ely, UK), GFAP (polyclonal, 1:400; DakoCytomation), and BrdU (monoclonal, 1:100; Accurate Chemicals) were used with secondary anti-mouse and anti-rabbit antibodies coupled to Texas Red and FITC (each 1:200; Dianova, Hamburg, Germany) as well as a biotinylated anti-rat and FITC-avidin (1:600 and 1:200; both from Vector Laboratories). Slices were coverslipped with Vectashield (Vector Laboratories) and analyzed using a confocal microscope (Leica, Wetzlar, Germany). Counting of interneurons in the stratum oriens and hilus of the dorsal hippocampus was performed on six to eight coronal slices. Counting of BrdU- and Ki67-positive cells was performed on 8-10 sagittal slices of the dorsal hippocampus. The density of BrdU-positive cells was determined as the number of BrdU-positive cells divided by the days of BrdU application for the dentate gyrus (DG) of one sagittal slice. Because heterogeneity existed among individual mice of the $\mathrm{Tg}^{\mathrm{Cre}}$ line (Shimshek et al., 2005), the induced loss of GluR-B in forebrain of $G l u R-B^{\Delta F b}$ mice was confirmed by immunohistochemistry. Hematoxylin/eosin (H/E) staining was performed on paraffin slices. Slices were dewaxed with xylol, rehydrated, and stained with Gill's hematoxylin number 3 and eosin Y (PolySciences, Warrington, PA). Hippocampal pyramidal cell density in cells per square millimeters was assessed on three sagittal sections. Data are presented as mean \pm SEM. Statistical significance was evaluated by two-tailed, unpaired Student's $t$ test.

Mossy fiber visualization by Timm stain and quantification by Timm index. Timm staining was performed as described previously (Danscher, 1982 ) with some modifications. Briefly, $1 \mathrm{~h}$ after intraperitoneal injection of $\mathrm{Na}_{2} \mathrm{SeO}_{3}(15 \mathrm{mg} / \mathrm{kg})$, mice were anesthetized with halothane (Hoechst, Frankfurt, Germany) and transcardially perfused with $1 \%$ PBS at $20^{\circ} \mathrm{C}$. Brains were isolated and frozen on solid $\mathrm{CO}_{2}$ and stored at $-70^{\circ} \mathrm{C}$. Cryostat sections $(15 \mu \mathrm{m})$ were cut through the entire extent of the hippocampus and mounted on poly-L-lysine-coated slides, fixed in $4 \%$ paraformaldehyde (PFA) for $5 \mathrm{~min}$, dehydrated in $100 \%$ ethanol, and stored at $4^{\circ} \mathrm{C}$. Before development, mounted sections were dipped in $0.5 \%$ gelatin developed in the dark for $10-30 \mathrm{~min}$ in developer solution (100 $\mathrm{ml} 50 \%$ gum arabic solution, $20 \mathrm{ml}$ of citrate buffer of $25.5 \%$ citric acid and $23.5 \%$ Tri-sodium citrate, $30 \mathrm{ml}$ of $3.3 \%$ hydroquinone, $70 \mathrm{ml}$ of $\mathrm{ddH}_{2} \mathrm{O}$, with addition of $30 \mathrm{ml}$ of $0.7 \% \mathrm{Ag}$-lactate added immediately before use). After washing, the slices were dehydrated in 100\% ethanol, cleared in $100 \%$ xylol, and coverslipped. Timm staining was quantified by NIH Image 1.62. The Timm index was assessed by dividing the number of granules by the length of the granule cell layer. Data are presented as mean \pm SEM. Statistical significance was evaluated by two-tailed, unpaired Student's $t$ test.

BrdU application. For oral application, $1 \mathrm{mg} / \mathrm{ml}$ BrdU (Sigma) was dissolved in drinking water containing $1 \%$ sucrose. Duration of applica- 
tion lasted for $1-2$ weeks. Alternatively, $50 \mu \mathrm{g}$ of $\mathrm{BrdU}$ in $0.9 \% \mathrm{NaCl}$ per gram of body weight were intraperitoneally injected every second day for 1 week.

Pretreatment of brain slices for BrdU and Ki67 antibody detection. For enzymatic immunohistochemical and immunofluorescence detection of BrdU, brain slices were pretreated as described previously (Kempermann et al., 1997a,b; Parent et al., 1997). For detection of Ki67, cryostat brain slices were pretreated with citrate buffer $(10 \mathrm{~mm}$ citric acid and $10 \mathrm{~mm}$ $\mathrm{Na}$-citrate) for $40 \mathrm{~min}$ at $80^{\circ} \mathrm{C}$.

Cobalt uptake. Experiments for $\mathrm{Co}^{2+}$ uptake (Engelman et al., 1999) were slightly modified. In brief, mice were killed with halothane. The brain was removed, and transverse slices $(250 \mu \mathrm{m})$ were cut with a vibroslicer in cold Ringer's solution (Biometra, Göttingen, Germany) bubbled with $95 \% \mathrm{O}_{2} / 5 \% \mathrm{CO}_{2}, \mathrm{pH} 7.4$. Slices were allowed to recover for $1 \mathrm{~h}$ at $28^{\circ} \mathrm{C}$ in Ringer's solution containing tetrodotoxin (TTX) $(0.5 \mu \mathrm{M})$. All of the following incubations were performed at $20^{\circ} \mathrm{C}$ in bubbled solutions with $95 \% \mathrm{O}_{2} / 5 \% \mathrm{CO}_{2}, \mathrm{pH}$ 7.4. Slices were prestimulated for $15 \mathrm{~min}$ in a Krebs' solution (in mM: $50 \mathrm{NaCl}, 2.5 \mathrm{KCl}, 26 \mathrm{NaHCO}_{3}, 1.25 \mathrm{NaH}_{2} \mathrm{PO}_{4}$, 25 glucose, $0.5 \mathrm{CaCl}_{2}$, and $2 \mathrm{MgCl}_{2}$ ) with $0.5 \mu \mathrm{M}$ TTX and DL-2-amino5 -phosphonopentanoic acid (DL-AP-5) $(100 \mu \mathrm{M})$. As a control, slices were additionally incubated with the AMPA antagonist 6-nitro-7sulfamoylbenzo[f]quinoxaline-2,3-dione (NBQX) (20 $\mu \mathrm{M})$. Subsequently, slices were stimulated with kainate $(20 \mu \mathrm{M})$ for $20 \mathrm{~min}$ in the Krebs' solution, which in addition contained $\mathrm{CoCl}_{2}(1.5 \mathrm{~mm})$. Slices were then washed for $10 \mathrm{~min}$ in EDTA $(0.5 \mathrm{M})$ containing Krebs' solution without divalent ions (in mm: $50 \mathrm{NaCl}, 2.5 \mathrm{KCl}, 26 \mathrm{NaHCO}_{3}, 1.25$ $\mathrm{NaH}_{2} \mathrm{PO}_{4}, 25$ glucose, and 135 sucrose) and then washed for $5 \mathrm{~min}$ in a Krebs' solution without divalent ions and EDTA. Intracellular $\mathrm{Co}^{2+}$ was precipitated by incubating in Krebs' solution without divalent ions containing $0.12 \% \mathrm{NH}_{4} \mathrm{~S}$ for $5 \mathrm{~min}$. Slices were then washed in Krebs' solution without divalent ions for $5 \mathrm{~min}$ and fixed overnight in $4 \%$ PFA in $0.1 \mathrm{M}$ PBS at $4^{\circ} \mathrm{C}$. After slices were equilibrated in $30 \%$ sucrose in $0.1 \mathrm{~m} \mathrm{PBS}$, they were mounted with Cryomedium (Leica, Nussloch, Germany), cut into 22- $\mu \mathrm{m}$-thick sections on a cryostat, and mounted on Superfrost slides (Menzel, Braunschweig, Germany). For silver intensification, sections were incubated in $2 \% \mathrm{Na}_{2} \mathrm{WO}_{4}$ for $10 \mathrm{~min}$ and then in developer solution [ 8 parts of $\mathrm{AgNO}_{3}$ solution: $1 \%$ Triton $\mathrm{X}-100,7.5 \% \mathrm{CH}_{3} \mathrm{COOH}$, $30.3 \mathrm{~mm}$ Na-acetate, $2.94 \mathrm{~mm} \mathrm{AgNO}_{3} ; 1$ part of $5 \% \mathrm{Na}_{2} \mathrm{WO}_{4}$; 1 part of $0.25 \%$ ascorbic acid in the dark for 7 min and washed in $2 \% \mathrm{Na}_{2} \mathrm{WO}_{4}$, dried, rinsed in 100\% xylol, and coverslipped with eu-kitt (O. Kindler)].

Current-voltage relationships. The brains were removed from deeply anesthetized (halothane) mice at P42, and transverse hippocampal slices $(250 \mu \mathrm{m})$ were prepared and incubated for $30 \mathrm{~min}$ at $37^{\circ} \mathrm{C}$ in artificial CSF (ACSF) (in mm: $125 \mathrm{NaCl}, 25 \mathrm{NaHCO}_{3}, 2.5 \mathrm{KCl}, 1.25 \mathrm{NaH}_{2} \mathrm{PO}_{4}, 1$ $\mathrm{MgCl}_{2}, 25$ glucose, and $2 \mathrm{CaCl}_{2}, \mathrm{pH}$ 7.4) bubbled with $95 \% \mathrm{O}_{2} / 5 \% \mathrm{CO}_{2}$. Patch pipettes were pulled from borosilicate glass capillaries and had resistances of 4-7 M $\Omega$ when filled with $125 \mathrm{~mm}$ Cs-gluconate, $20 \mathrm{~mm}$ CsCl, 10 mm NaCl, 10 mм HEPES, 0.2 mm EGTA, 4 mm MgATP, 0.3 mm $\mathrm{Na}_{3} \mathrm{GTP}, 100 \mu \mathrm{M}$ spermine, and $2.5 \mathrm{~mm}$ QX-314 [N-(2,6-dimethylphenylcarbamoylmethyl) triethylammonium chloride], pH 7.3 (290$305 \mathrm{mOsm}$ ). Series resistances and input resistances were continuously monitored by measuring the peak and steady-state currents in response to hyperpolarizing pulses $(-5 \mathrm{mV}, 20 \mathrm{~ms})$. Liquid junction potentials were corrected. Synaptic currents were activated between -70 and +40 $\mathrm{mV}$ in $10 \mathrm{mV}$ steps by stimulating the Schaffer collaterals $150 \mu \mathrm{m}$ distant from the CA1 cell body with a glass electrode filled with $1 \mathrm{M} \mathrm{NaCl}$. AMPA receptor currents were recorded in the presence of $1 \mathrm{mM} \mathrm{MgCl}_{2}, 50 \mu \mathrm{M}$ DL-AP-5, $10 \mu \mathrm{M}$ bicuculline methiodide (Sigma), and $1 \mu \mathrm{M}$ CGP 55845 [(2S)-3-[[(1S)-1-(3,4-dichlorophenyl)ethyl] amino-2-hydroxypropy1] (phenylmethyl)phosphinic acid] (Tocris Cookson via Biotrend, Koeln, Germany). Single traces were analyzed and illustrated. Data are presented as mean \pm SEM. Statistical significance was evaluated by twotailed, unpaired Student's $t$ test.

Synaptic excitability. Mice were killed with halothane. The brain was removed, and transverse slices $(400 \mu \mathrm{m})$ were cut from each hippocampus with a vibroslicer in cold $\left(4^{\circ} \mathrm{C}\right) \mathrm{ACSF}$ (in mM: $124 \mathrm{NaCl}, 2 \mathrm{KCl}, 1.25$ $\mathrm{KH}_{2} \mathrm{PO}_{4}, 2 \mathrm{MgSO}_{4}, 1 \mathrm{CaCl}_{2}, 26 \mathrm{NaHCO}_{3}$, and 12 glucose, $\mathrm{pH}$ 7.4) bubbled with $95 \% \mathrm{O}_{2} / 5 \% \mathrm{CO}_{2}$. Slices were placed in a humidified interface chamber at $28-32^{\circ} \mathrm{C}$ and perfused with ACSF, supplemented with $2 \mathrm{~mm}$
$\mathrm{CaCl}_{2}$. Orthodromic synaptic stimuli $(<700 \mu \mathrm{A}, 0.1 \mathrm{~Hz})$ were delivered through a tungsten electrode placed in stratum radiatum of the CA1 region. The presynaptic volley and the field EPSP (fEPSP) were recorded by a glass electrode (filled with ACSF) placed in the stratum radiatum, whereas an electrode placed in the stratum pyramidale monitored the population spike. After a period of at least $20 \mathrm{~min}$ with stable responses, we stimulated the afferent fibers at $0.1 \mathrm{~Hz}$ with increasing strength (increasing the stimulus duration in steps of $10 \mu \mathrm{s}$ from 0 to $150 \mu \mathrm{s}$; five consecutive stimulations at each step). A similar approach was used to elicit paired-pulse responses ( $50 \mathrm{~ms}$ interstimulus interval; the two stimuli being equal in strength). To assess synaptic transmission, we measured the amplitude of the presynaptic volley and the fEPSP in millivolts at different stimulation strengths. The population spike amplitude was measured as distance between the maximal population spike peak and a line joining the maximum prespike and postspike fEPSP positivities. To pool data from the paired-pulse experiments, we selected responses to stimulation strength just below the threshold for eliciting a population spike on the second fEPSP. Data are pooled across mice of the same group and presented as mean \pm SEM. Statistical significance was evaluated by a Student's two-tailed $t$ test.

Long-term potentiation recordings. Orthodromic synaptic stimulation in CA1 was delivered alternately through two tungsten electrodes $(0.2$ $\mathrm{Hz}$ ) to activate synapses in apical (stratum radiatum) and basal (stratum oriens) dendrites, respectively. Extracellular potentials were monitored by glass electrodes filled with ACSF, which were placed in the corresponding synaptic layers. The stimulation strength was set to elicit an fEPSP with a slope $40-70 \%$ of the slope necessary for generating a detectable population spike. After obtaining stable synaptic responses in both pathways for at least $15 \mathrm{~min}$, one pathway was tetanized (with either a single $100 \mathrm{~Hz}$ tetanization for $1 \mathrm{~s}$ or four such tetanizations given at 5 min intervals), and the other pathway served as a control. To standardize tetanization strength in different experiments, the tetanic stimulation strength was set in response to a single shock at an intensity just above the threshold for generating a population spike. Synaptic efficacy was assessed measuring the slope of the fEPSP in the middle third of its rising phase. Six consecutive responses ( $1 \mathrm{~min}$ ) were averaged and normalized to the mean value recorded $4-7 \mathrm{~min}$ before tetanic stimulation. In some experiments, DL-AP-5 (50 $\mu \mathrm{M}$; Sigma) was present during the recordings. Data are mean \pm SEM; the statistical significance of long-term potentiation (LTP) levels between tetanized and nontetanized inputs were calculated by Student's paired two-tailed $t$ test. LTP levels between the same group of mice or resulting from different tetanization paradigms were evaluated by linear mixed-model statistical analysis.

Behavioral tests. Before the training, mice were familiarized to the experimenter, blind to the genotypes of the mice. For habituation, each mouse was handled for at least five sessions (10 min per mouse per session). For the T- and Y-maze, mice were assigned to a restricted food diet aimed at keeping the mice at $85 \%$ of their free-feeding weight. Mice were accustomed to the maze and to the "bait" (sweetened condensed milk; $4 \%$ fat, $10 \%$ fat-free dry milk, $22.5 \%$ sugar) during a habituation period that lasted several sessions.

Spatial working memory ( $T$-maze). The T-maze was performed as described previously (Reisel et al., 2002) except that mice received two sessions of four trials (intertrial interval, $10-20 \mathrm{~min}$ ) per day for $4 \mathrm{~d}$. A wooden T-maze with a start arm $(47 \times 10 \times 10 \mathrm{~cm})$ and two identical goal arms $(35 \times 10 \times 10 \mathrm{~cm})$ was painted in black. A metal food well was located $3 \mathrm{~cm}$ from the end of each goal arm. Every trial of the training included two runs, sample run and choice run. On each trial, the sample arm was assigned to one of the two target arms randomly, and the mouse was directed to the sample arm, in which it was rewarded with $30 \mu \mathrm{l}$ of bait. Five to $10 \mathrm{~s}$ after the mouse completed the sample run, the mouse received the choice run, during which the mouse had to choose one of the two accessible arms. If the mouse chose the arm that was not visited in the sample run (successful alternation), it was baited. The numbers of correct choices were recorded. Data are given in mean \pm SEM.

Spatial reference memory (elevated $Y$-maze). We used an elevated Y-maze, consisting of three arms without walls (angle, $120^{\circ}$; arm, $50 \times$ $10 \times 0.5 \mathrm{~cm}$ ) made of black painted wood (Reisel et al., 2002). Daily training sessions consisted of 10 trials (one session per day) with an 
A
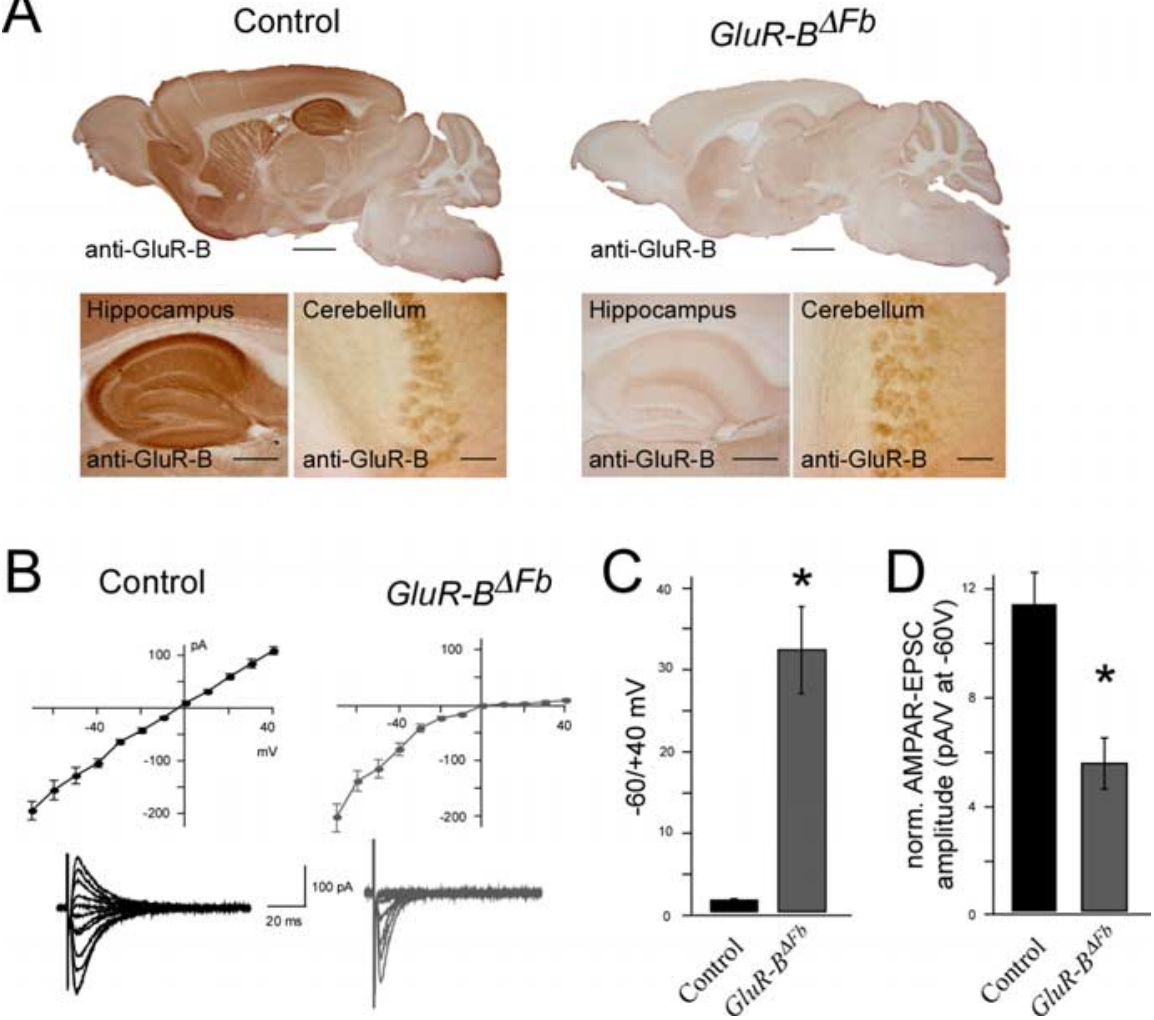

Figure 1. Forebrain-specific depletion of GluR-B.A, Immunohistochemically stained sections for GluR-B from control (left) and $G_{l} R_{R}-B^{\Delta F b}$ (right) mice. Hippocampus and cerebellum are shown at higher magnification (bottom row). Scale bars: overview, 1.4 $\mathrm{mm}$; hippocampus, $500 \mu \mathrm{m}$; cerebellum, $50 \mu \mathrm{m} . \boldsymbol{B}, I-V$ relationships and representative AMPA receptor-mediated currents at different holding potentials of control and GluR-B $B^{\triangle F b}$ mice. C, Quantitative representation of the rectification index measured at -60 and $+40 \mathrm{mV}$ for control and GluR-B $B^{\Delta F b}$ mice. ${ }^{*} p<0.05$. D. AMPA receptor-mediated EPSCs (in picoamperes) normalized to the stimulation strength (in volts) for control and GluR-B $B^{\Delta F b}$ mice. ${ }^{*} p<0.05$.

intertrial interval of 10-15 min. One of the three arms, positioned in front of a checkerboard design, was assigned as the target arm. The visits of this arm were rewarded with the bait. The other two arms of the Y-maze were used as start arm in a random order. On a given trial, the mouse was placed at the distal end of the start arm, facing the arm junction, and the trial was initiated. During the first two sessions, the mouse was allowed to enter and reenter arms until it found the bait. After consuming the bait, the mouse was returned to the home cage. From session three, the trials during which the mouse entered the target arm without first entering any other arm were designated as successful trials. Between each trial, the maze was rotated in random directions by $120^{\circ}$ to prevent usage of olfactory, visual, or tactile cues unique to a particular arm. To exclude the possibility that mice used olfactory information from the bait rather then spatial information associated with the baited arm, in session 11, the reward was given after the mouse entered the baited arm. All mice ( $n=10$ per group) tested under these conditions showed no change in success rate compared with the previous session, suggesting that mice used spatial cues to perform the task. In the last session, we reduced and masked the external spatial cues by placing a wooden, meshed curtain around the Y-maze. Data are given in mean \pm SEM.

Open-field exploration. General motor ability of mice was studied in an open field $(60 \times 60 \times 30 \mathrm{~cm})$ for $6 \mathrm{~min}$. The walls of the wooden arena were painted in black, and the ground was white. Motor performance of the mice was quantified by in-house software written in Matlab (MathWorks, Natick, MA). A camera (Panasonic WV-BP330/GE; Suzhou Matsushita Communication Industrial, Suzhou, China) was positioned 100 $\mathrm{cm}$ above the arena that acquired images at 25 frames/s with a spatial resolution of $0.12 \mathrm{~mm} /$ pixel under white light (light intensity, $62 \pm 2$ lux on the ground surface of the arena). For each frame acquired, the software located the mouse in the environment and extracted the $x-y$ coor- dinate of the subject by the center of mass calculation. Distance traveled between two successive frames, path traveled throughout the experiment, and the statistics of the motor activity were calculated using vector analysis algorithms. Data are given in mean \pm SEM.

Novel object exploration. To test the ability of mice to respond to sensory stimuli in the environment, we placed objects novel to the mice in the open-field arena, after animals were run in the arena for the open-field exploration task, and observed the exploratory response of the mice to these sensory stimuli. Five distinct objects were used for this experiment: (1) a green plastic wire spool (diameter, $5 \mathrm{~cm}$; length, 10 $\mathrm{cm}$ ) with sand paper (average particle diameter of $35 \mu \mathrm{m}$ ) attached to one of its sides, (2) a multicolor cross-shaped Lego piece measuring $8.0 \times 6.5 \times 6.0 \mathrm{~cm},(3)$ a semi-conical silicon bottle stopper with a diameter of $7.0 \mathrm{~cm}$ on the top and $8.2 \mathrm{~cm}$ at the bottom, (4) two wooden pieces glued together to form a L-shape and covered with sandpaper with average particle diameter of 200 and $100 \mu \mathrm{m}$, and (5) a Lego construct formed into a pool with dimensions of $3.2 \times 4.8 \mathrm{~cm}$ (inner) and $6.4 \times 8.0 \mathrm{~cm}$ (outer). The construct had uneven walls: the shortest one was 3.2, and the tallest one was 6.7 $\mathrm{cm}$ high. Mobility of the mice in the arena as well as the object exploration by the mice were analyzed by the software described above with an additional toolbox calculating distance of the subject to the objects of interest in the environment. Novel object exploration task lasted 6 min, which was given $\sim 4$ min after the openfield exploration paradigm. Between the two sessions, the arena was not cleaned. However, both the arena and objects were cleaned with $90 \%$ ethanol after each mouse completed the tasks. Exploration trainings were performed under white noise (intensity, $75 \mathrm{~dB})$. Data are given in mean \pm SEM.

\section{Results}

\section{Mice with conditional GluR-B removal in principal neurons} of the forebrain

We generated mice having inactivated GluR-B alleles in principal neurons of the juvenile and mature forebrain (Shimshek et al., 2005). In brief, the $\alpha$ calcium/calmodulin-dependent kinase II ( $\alpha$ CaMKII) promoter-driven transgene for Cre recombinase of $\mathrm{Tg}^{\mathrm{Cre} 4}$ mice (Mantamadiotis et al., 2002) was introduced into

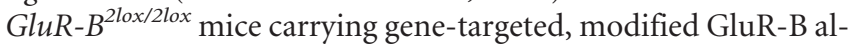
leles (supplemental Fig. 1, available at www.jneurosci.org as supplemental material). In the resulting $G l u R-B^{\Delta F b}$ mice, the induced forebrain-specific loss of GluR-B was visualized by immunostaining of mouse brains (Fig. 1A).

\section{Principal neurons devoid of GluR-B contain $\mathrm{Ca}^{2+}$-permeable AMPA receptors}

First, we confirmed the GluR-B depletion in the forebrain of $G l u R-B^{\Delta F b}$ mice by analyzing AMPA receptor properties in CA1 pyramidal neurons in acute brain slices from P42 mice. AMPA receptor currents in neurons of control mice $(n=8)$ yielded the expected linear $I-V$ relationship, whereas in CA1 cells $(n=14)$ of GluR-B $B^{\Delta F b}$ mice, AMPA receptor currents showed inward rectification at positive holding potentials (Fig. $1 B$ ), which is characteristic of $\mathrm{Ca}^{2+}$-permeable AMPA receptors lacking GluR-B (Washburn and Dingledine, 1996). Quantification of rectifica- 

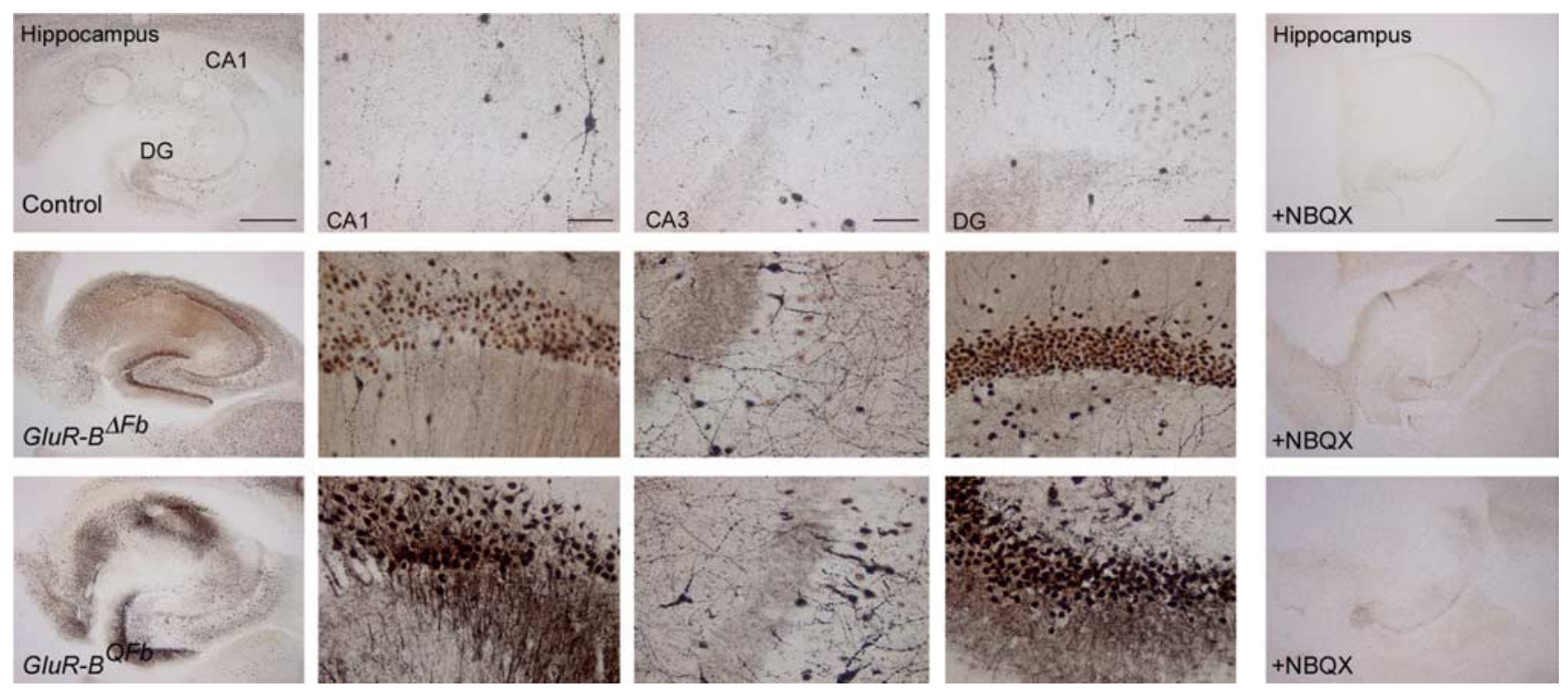

Figure 2. $\mathrm{CO}^{2+}$ uptake in acute brain slices from control, GluR-B $B^{\Delta F b}$, and GluR-B $B^{Q F b}$ mice. Overview of $C_{0}{ }^{2+}$ uptake experiments of the hippocampus (left panels) and higher-magnification pictures of $C A 1, C A 3$, and DG for control (top row), GluR-B $B^{\Delta F b}$ (middle row), and GluR-B $B^{Q F b}$ (bottom row) mice. Overview pictures of the hippocampus from C $0^{2+}$ uptake experiments in the presence of NBQX are shown in the right panels. Scale bars: hippocampus, $500 \mu \mathrm{m} ; C A 1, C A 3, D G, 50 \mu \mathrm{m}$.

Table 1. Quantitative analyses of histochemical experiments

\begin{tabular}{|c|c|c|c|c|}
\hline & \multirow{2}{*}{$\begin{array}{l}\text { TIMM index } \\
\text { (granules/length of DG) }\end{array}$} & \multicolumn{3}{|l|}{$\mathrm{H} / \mathrm{E}$ stain (cells/mm²) } \\
\hline & & CA1 & CA3 & DG \\
\hline \multirow{5}{*}{$\begin{array}{l}\text { Control } \\
\text { GluR-B } B^{\Delta F b} \\
\text { GluR-B } B^{\text {QFb }}\end{array}$} & $124 \pm 12 ; n=4$ & $3975 \pm 376 ; n=3$ & $1914 \pm 49 ; n=3$ & $9606 \pm 1213 ; n=3$ \\
\hline & $303 \pm 31, n=3 ; p<0.05$ & $3964 \pm 350 ; n=3$ & $1498 \pm 100 ; n=3 ; p<0.05$ & $9268 \pm 1190 ; n=3$ \\
\hline & $406 \pm 28 ; n=4 ; p<0.05$ & $3863 \pm 125 ; n=3$ & $1802 \pm 100 ; n=3$ & $9764 \pm 856 ; n=3$ \\
\hline & & \multicolumn{3}{|l|}{ Interneurons } \\
\hline & & $\operatorname{parv}^{+} / \mathrm{DG}$ & sst $^{+} /$length of SO & Sst $^{+} /$hilus \\
\hline \multirow{3}{*}{\multicolumn{2}{|c|}{$\begin{array}{l}\text { Control } \\
\text { GluR-B } B^{\Delta F b} \\
\text { GluR-B } B^{Q F b}\end{array}$}} & $24 \pm 0.9 ; n=4$ & $28 \pm 2.2 ; n=3$ & $34 \pm 1.4 ; n=3$ \\
\hline & & $15 \pm 1.1 ; n=5 ; p<0.05$ & $26 \pm 2.3 ; n=5$ & $34 \pm 2.4 ; n=5$ \\
\hline & & $16 \pm 0.8 ; n=5 ; p<0.05$ & $18 \pm 0.3 ; n=3 ; p<0.05$ & $22 \pm 2.6 ; n=3 ; p<0.05$ \\
\hline
\end{tabular}

Timm index, Granule/length of dentate gyrus, pyramidal cell density, number of parvalbumin- and somatostatin-positive interneurons for the dentate gyrus and hilus of coronal brain slices, and number of somatostatin-positive interneurons divided by the length of the stratum oriens for coronal brain slices from control, GluR-B $B^{\triangle F b}$, and GluR-B ${ }^{Q F b}$ mice. Data are shown as mean \pm SEM. parv + , Parvalbumin positive; sst + , somatostatin positive; $S 0$, stratum oriens.

tion $(-60$ and $+40 \mathrm{mV}$ ) (Fig. $1 C$ ) revealed a 20 -fold increase $(32.08 \pm 5.33 ; p<0.05)$ in GluR-B $B^{\Delta F b}$ mice when compared with neurons from control mice $(1.45 \pm 0.17)$. We also noticed that the EPSCs normalized to the stimulation strength (picoamperes per volt) were significantly smaller in CA1 pyramidal cells of GluR- $B^{\Delta F b}$ mice $(5.4 \pm 1.0 \mathrm{pA} / \mathrm{V} ; n=13)$ compared with cells from control mice ( $11.4 \pm 1.1 \mathrm{pA} / \mathrm{V} ; n=6)$ (Fig. $1 D)$, providing evidence for reduced excitatory transmission when GluR-B was genetically deleted.

We further visualized the presence of the GluR-B lacking $\mathrm{Ca}^{2+}$-permeable AMPA receptors in the hippocampus of GluR$B^{\Delta F b}$ mice by AMPA receptor-mediated $\mathrm{Co}^{2+}$ influx after stimulation by kainate in acute brain slices in the presence of the NMDA receptor antagonist DL-AP-5 and the sodium channel blocker TTX (Fig. 2). GluR-B $B^{Q F b}$ mice were used as controls. In these mice, the $\mathrm{Ca}^{2+}$ influx through AMPA receptors was directly visualized at CA3-to-CA1 synapses (Krestel et al., 2004). In control mice, only interneurons showed $\mathrm{Co}^{2+}$ staining (Fig. 2), because hippocampal CA1 pyramidal and DG granule cells express AMPA receptors impermeable to $\mathrm{Ca}^{2+}$ and $\mathrm{Co}^{2+}$. In contrast, $G l u R-B^{\Delta F b}$ and $G l u R-B^{Q F b}$ mice exhibited prominent $\mathrm{Co}^{2+}$ staining of CA1 pyramidal and DG granule cells, showing the AMPA receptor switch and the presence of $\mathrm{Ca}^{2+}$-permeable AMPA re- ceptors in those neurons (Fig. 2, middle and bottom rows). In all of our experiments, the $\mathrm{Co}^{2+}$ uptake was mediated by the activation of AMPA receptors because the AMPA receptor blocker NBQX prevented $\mathrm{Co}^{2+}$ staining in all genotypes (Fig. 2, right part of the four rows). We were unable to detect $\mathrm{Co}^{2+}$ uptake in CA3 pyramidal cells (Fig. 2). This may be attributable to insufficient removal of the floxed GluR-B gene segment in CA3 pyramidal cells, which have lower functional expression of the $\alpha$ CaMKIICre transgene (Krestel et al., 2004; Shimshek et al., 2005).

\section{Cellular changes after forebrain specific inactivation of the GluR-B gene}

The forebrain, principal neuron-specific, postnatal GluR-B deletion had long-lasting functional and structural consequences. Most of these were not directly mediated by changes in AMPA receptor signaling but were more likely secondary to the AMPA receptor-mediated $\mathrm{Ca}^{2+}$ influx. In addition to a modest sprouting of the mossy fiber axon terminals in DG (quantified as Timm index) (Table 1, Fig. 3A), we also observed a significant reduction in the number of parvalbumin-positive interneurons in DG (Fig. $3 B$, Table 1). Because these GABAergic interneurons express little GluR-B (Leranth et al., 1996; He et al., 1998; Moga et al., 2002) and because Cre is not active in these cells, the observed loss of 
A
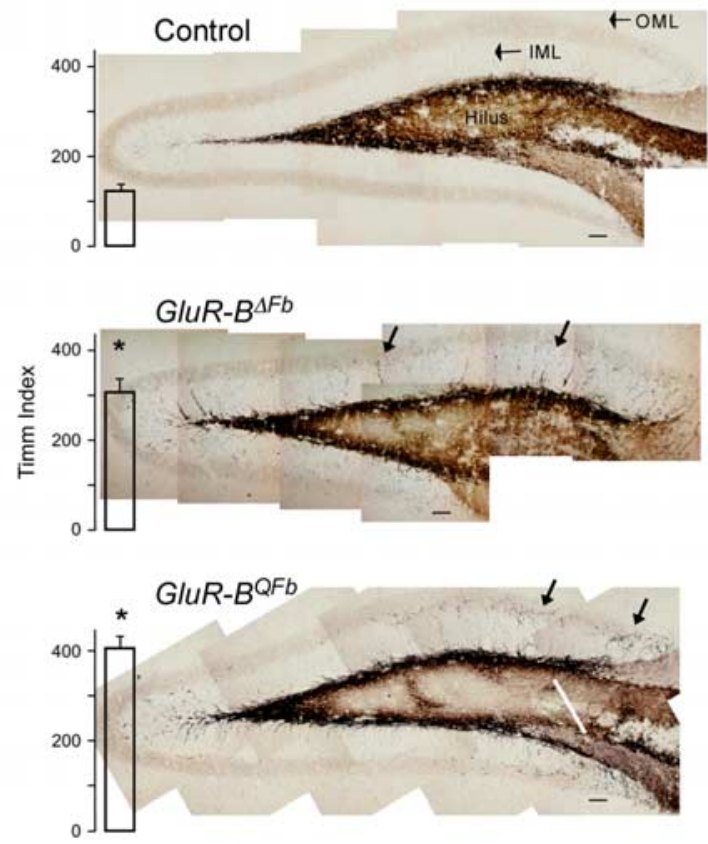
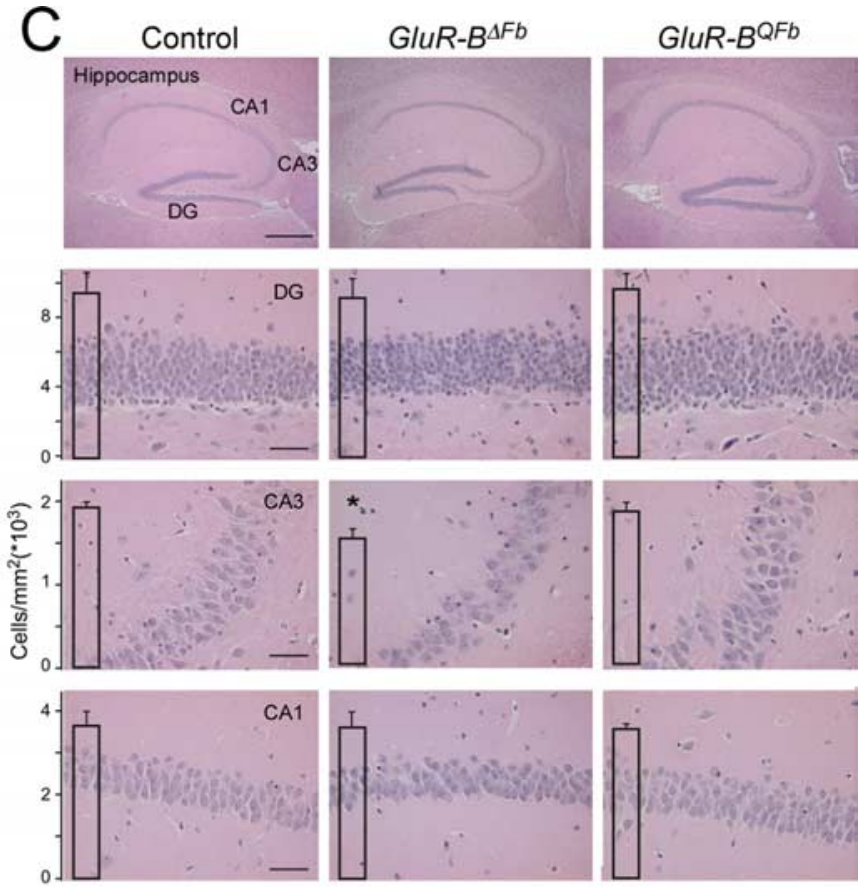

$\mathrm{D}$
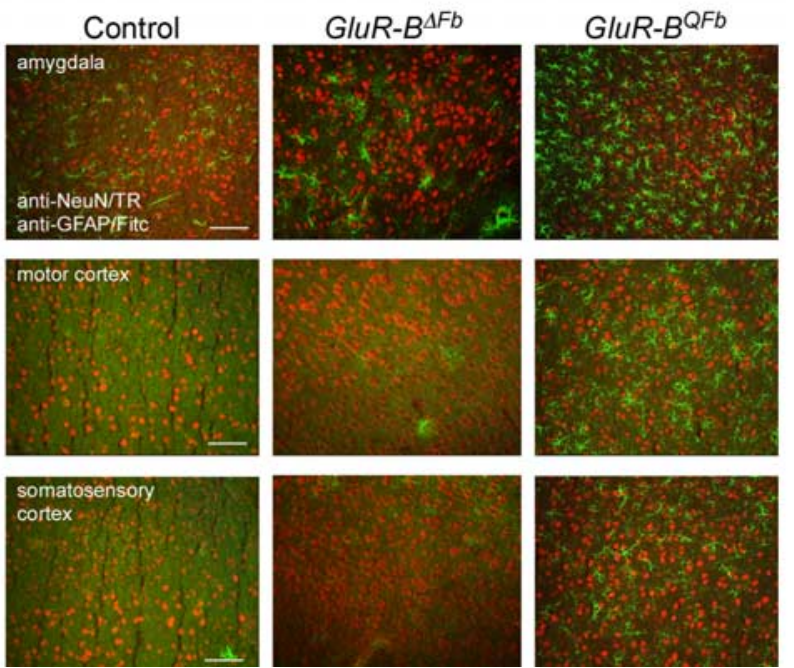

Figure 3. Cellular effects of chronic forebrain-specific expression of $\mathrm{Ca}^{2+}$-permeable AMPA receptors. $A$, Timm stain detecting mossy fiber sprouting in the DG in control, GluR-B ${ }^{\Delta F b}$, and GluR-B $B^{Q F b}$ mice as indicated. Black arrows, Zinc granules in the outer molecular layer (OML) and inner molecular layer (IML). Scale bars, $50 \mu \mathrm{m}$. $\boldsymbol{B}$, Reduced number of hippocampal interneurons in GluR-B $B^{\Delta F b}$ and GluR-B $B^{Q F b}$ mice. Immunohistochemical labeling of parvalbumin-positive (parv) cells in the DG (top row) and somatostatin-positive (sst) cells in the stratum oriens (SO; middle row) and DG (bottom row) in the different genotypes as indicated. Scale bars, $50 \mu \mathrm{m}$. C, Reduced pyramidal cell density in GluR- $B^{\Delta F b}$ mice. Overview of the hippocampus (top row) and higher magnification with hematoxylin/eosin staining for evaluating pyramidal cell density in hippocampi of control, GluR-B $B^{\Delta F b}$, and GluR-B $B^{Q F b}$ mice as indicated. Scale bars: top row (hippocampus), 500 $\mu \mathrm{m}$; all other rows (CA1, CA3, DG), $50 \mu \mathrm{m}$. D, Increased GFAP-positive cells in GluR-B ${ }^{O F b}$ mice. Immunofluorescence double labeling with antibodies against GFAP (green) and NeuN (red) in cryostat sections from control, GluR-B $B^{\Delta F b}$, and GluR-B ${ }^{Q F b}$ mice taken from the indicated brain areas. Scale bars, $100 \mu \mathrm{m}$. Data are shown as mean \pm SEM. ${ }^{*} p<0.05$.

interneurons must be secondary to altered AMPA receptormediated neurotransmission in principal cells.

In the CA3 subfield, we detected a loss of principal neurons in GluR- $B^{\Delta F b}$ mice by H/E staining (Fig. $3 C$, Table 1). This pyramidal cell loss is not a direct effect of AMPA receptor-mediated $\mathrm{Ca}^{2+}$ influx either, because no loss of hippocampal pyramidal neurons was found in GluR-B $B^{Q F b}$ mice. In GluR-B $B^{Q F b}$ mice, we observed an increased number of GFAP-positive glia cells (Fig. $3 D$ ), probably resulting from recurrent epileptiform activity in these mice (Krestel et al., 2004), as in other epilepsy models and in human temporal lobe epilepsy (Steward, 1994; Stringer, 1996).
The number of GFAP-positive glia cells in GluR- $B^{\Delta F b}$ was similar to control mice (Fig. 3D). Furthermore, the interneuron loss in GluR$B^{Q F b}$ mice also included somatostatin-positive cells in hilus and stratum oriens of the CA1 (Fig. 3B, Table 1). In contrast to GluR-B $B^{Q F b}$ mice, we failed to observe seizure episodes in $G l u R-B^{\Delta F b}$ mice, which showed normal home cage behavior and epidural telemetric EEG recordings (H. E. Krestel, personal communication).

\section{Reduced neurogenesis in the absence of GluR-B}

The observed cellular alterations and the reduced AMPA receptor currents after GluR-B removal suggested changes in the excita- 
tory hippocampal activity in $G l u R-B^{\Delta F b}$ mice. As marker for ongoing neuronal activity in the hippocampus, we determined the extent of neurogenesis in the subgranular zone (SGZ) of the DG (for review, see Morimoto et al., 2004). As control for enhanced hippocampal activity, we used GluR-B ${ }^{Q F b}$ mice, which show hippocampal epileptic activity (Krestel et al., 2004). BrdU was administered to the different GluR-B genotypes for $6 \mathrm{~d}$, either orally or intraperitoneally, and BrdUpositive cells in DG were counted subsequently. A twofold increase in BrdUpositive cells was observed in the SGZ of GluR-B ${ }^{Q F b}$ mice $(13.6 \pm 1.3 ; n=7 ; p<$ 0.05 ) (Fig. 4A) when compared with littermate controls $(7.2 \pm 0.7 ; n=7)$. Similar results were obtained with the postmitotic marker Ki67, revealing a twofold increase in GluR- $B^{Q F b}$ mice (31.6 $\pm 5.8 ; n=4 ; p<$ 0.05 ) (Fig. $4 B$ ) relative to control mice $(16.2 \pm 1.5 ; n=4)$. Furthermore, 2 weeks after oral BrdU administration, BrdUpositive cells colocalizing with the neuronal marker NeuN appeared in the granule cell layer in GluR-B ${ }^{Q F b}$ but failed to do so in control mice (Fig. 4C). Thus, the incorporation of new neurons into the granule cell layer was accelerated in $G l u R-B^{Q F b}$

A

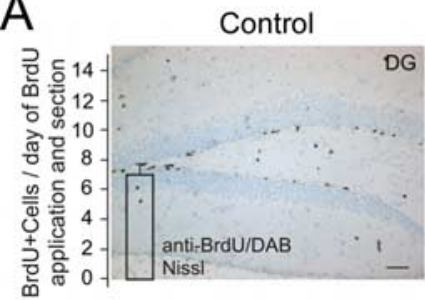

B

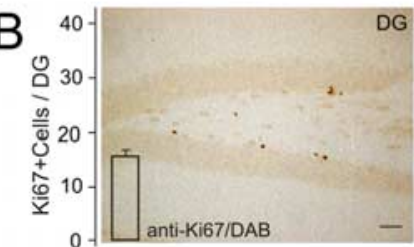

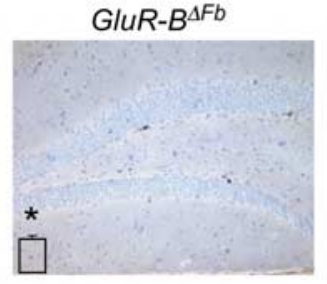
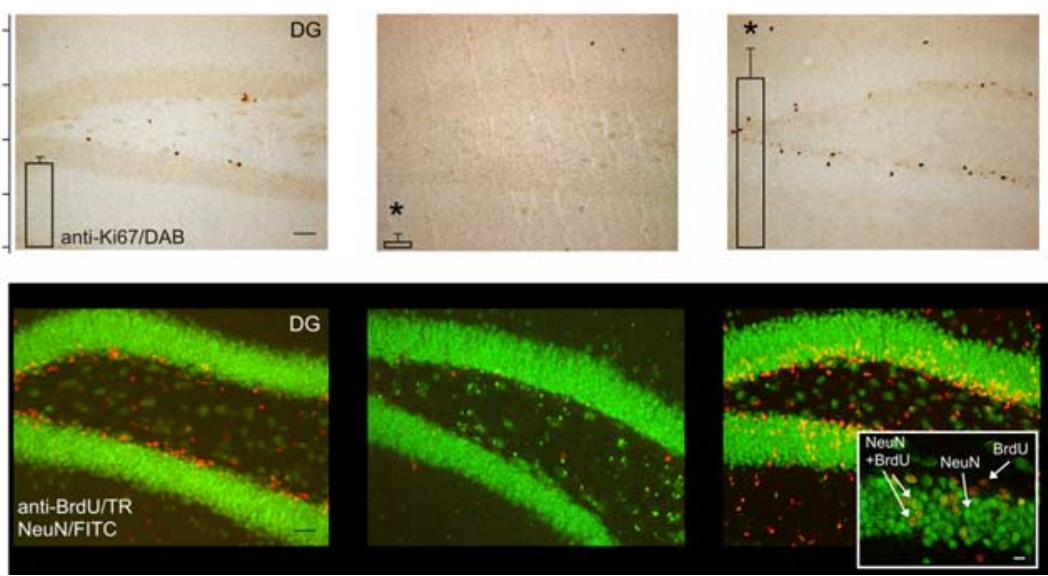

Figure 4. Reduced and increased cell proliferation in the subgranular cell layer in control, GluR-B $B^{\Delta F b}$, and GluR-B $B^{Q F b}$ mice, respectively. $\boldsymbol{A}$, Immunohistochemical labeling of BrdU-positive cells and NissI counterstaining. $\boldsymbol{B}$, Immunohistochemical labeling of Ki67-positive cells. C, Immunofluorescence labeling with antibodies against BrdU (red) and NeuN (green). Inset, High magnification of the granule cell layer in one confocal plain. TR, Texas Red. Scale bars: $A-C, 50 \mu \mathrm{m}$; inset in $C, 10 \mu \mathrm{m}$. Data are shown as mean \pm SEM. ${ }^{*} p<0.05$. mice, most likely as a consequence of recurrent epileptic activity. This was in contrast to GluR-B $B^{\Delta F b}$ mice in which BrdU-positive cells were virtually lacking $(2.3 \pm 0.2 ; n=5 ; p<0.05)$ (Fig. $4 A$ ), and only very few Ki67-positive cells could be detected in SGZ $(1.3 \pm 1.3 ; n=5 ; p<0.05)$ (Fig. $4 B$ ), which may well reflect the low hippocampal excitatory activity in these mice.

\section{Reduced excitatory synaptic transmission in $G l u R-B^{\Delta F b}$ mice}

To directly assess changes in excitatory synaptic transmission and synaptic excitability, we recorded simultaneously in the apical dendritic and soma layers in the CA1 region of hippocampal slices from GluR-B ${ }^{\Delta F b}$ and control mice. We measured the fiber volley, the fEPSP, and the population spike as a function of different stimulation strengths.

The stimulation strengths necessary to elicit fiber volleys of given amplitudes $(0.5,1.0$, and $1.5 \mathrm{mV})$ were significantly increased ( $p<0.01$ for all three) in GluR-B $B^{\Delta F b}$ mice $(11.9 \pm 1.5 \mathrm{nC}$, $n=55 ; 20.6 \pm 2.4 \mathrm{nC}, n=54$; and $26.0 \pm 3.1 \mathrm{nC}, n=48)$ compared with control mice $(6.8 \pm 0.7 \mathrm{nC}, n=48 ; 10.1 \pm 0.9 \mathrm{nC}$, $n=41$; and $13.2 \pm 1.3 \mathrm{nC}, n=35$ ) (Fig. $5 A$ ). This is best explained by a substantial reduction of the fiber density or the number of afferent fibers, with the latter explanation receiving support from the observed reduction in the number of CA3 pyramidal cells (Fig. 3C).

In GluR- $B^{\Delta F b}$ mice, evoked fEPSPs $(0.8 \pm 0.1 \mathrm{mV}, n=55$; $1.2 \pm 0.1 \mathrm{mV}, n=54$; and $1.5 \pm 0.1 \mathrm{mV}, n=48)$ for presynaptic fiber volleys of $0.5,1.0$, and $1.5 \mathrm{mV}$ were severely reduced ( $p<$ 0.01 for all three) and reached only 35,37 , and $38 \%$ of control values $(2.1 \pm 0.1 \mathrm{mV}, n=48 ; 3.3 \pm 0.2 \mathrm{mV}, n=41$; and $4.1 \pm 0.3$ $\mathrm{mV}, n=35$ ) (Fig. $5 B$ ). A comparison of paired-pulse facilitation failed to reveal a significant difference between $G l u R-B^{\Delta F b}$ $(1.52 \pm 0.03 ; n=56)$ and control $(1.46 \pm 0.02 ; n=48)$ mice (Fig.
$5 C)$, not supporting a presynaptic locus for the reduced excitatory transmission after loss of GluR-B.

In contrast to the reduced excitatory transmission, synaptic excitability was increased in GluR-B $B^{\Delta F b}$ mice. Thus, the threshold for generating a population spike was reduced to $71 \%(2.1 \pm 0.2$ $\mathrm{mV} ; n=23)$ compared with controls $(2.9 \pm 0.1 \mathrm{mV} ; n=47 ; p<$ 0.01 ) (Fig. $5 D$ ). Furthermore, whereas in controls a population spike was elicited in almost all experiments ( 47 of 48 ), the threshold for generating a population spike was reached in less than half of the experiments (23 of 56) in GluR-B $B^{\Delta F b}$ mice. Notably, in the paired-pulse facilitation experiments, once a population spike was elicited in the first response, the appearance of multiple population spikes was always ( 23 of 23 slices) observed in the second response in GluR-B ${ }^{\Delta F b}$ but not in control mice (1 of 48) (Fig. $5 E$ ). We described previously a similar trend in $G l u R-B^{Q F b}$ mice and considered it as a possible sign of epileptic brain activity (Krestel et al., 2004).

Thus, after functional GluR-B gene deletion, the hippocampal excitatory synaptic transmission was reduced, whereas synaptic excitability was increased.

\section{Normal LTP in GluR-B ${ }^{\Delta F b}$ mice}

Despite massive alterations in excitatory synaptic transmission and synaptic excitability at CA3-to-CA1 synapses, the CA3-toCA1 synapses were still able to undergo plastic changes. Tetanic stimulation of the afferent fibers, in either stratum radiatum or stratum oriens, produced a lasting, homosynaptic LTP of similar magnitude in both genotypes $(p=0.98)$. In control mice, the average fEPSP slope $40-45 \mathrm{~min}$ after tetanization was $139 \pm 8 \%$ $(n=19)$ of the pretetanic control value and $139 \pm 5 \%(n=22)$ in GluR-B ${ }^{\Delta F b}$ mice (Fig. $\left.6 A, C\right)$. Repeated tetanizations $(100 \mathrm{~Hz}, 1 \mathrm{~s}$, repeated four times at 5 min intervals) significantly increased the amount of LTP in both control $(164 \pm 7 \% ; n=17 ; p<0.05)$ and 

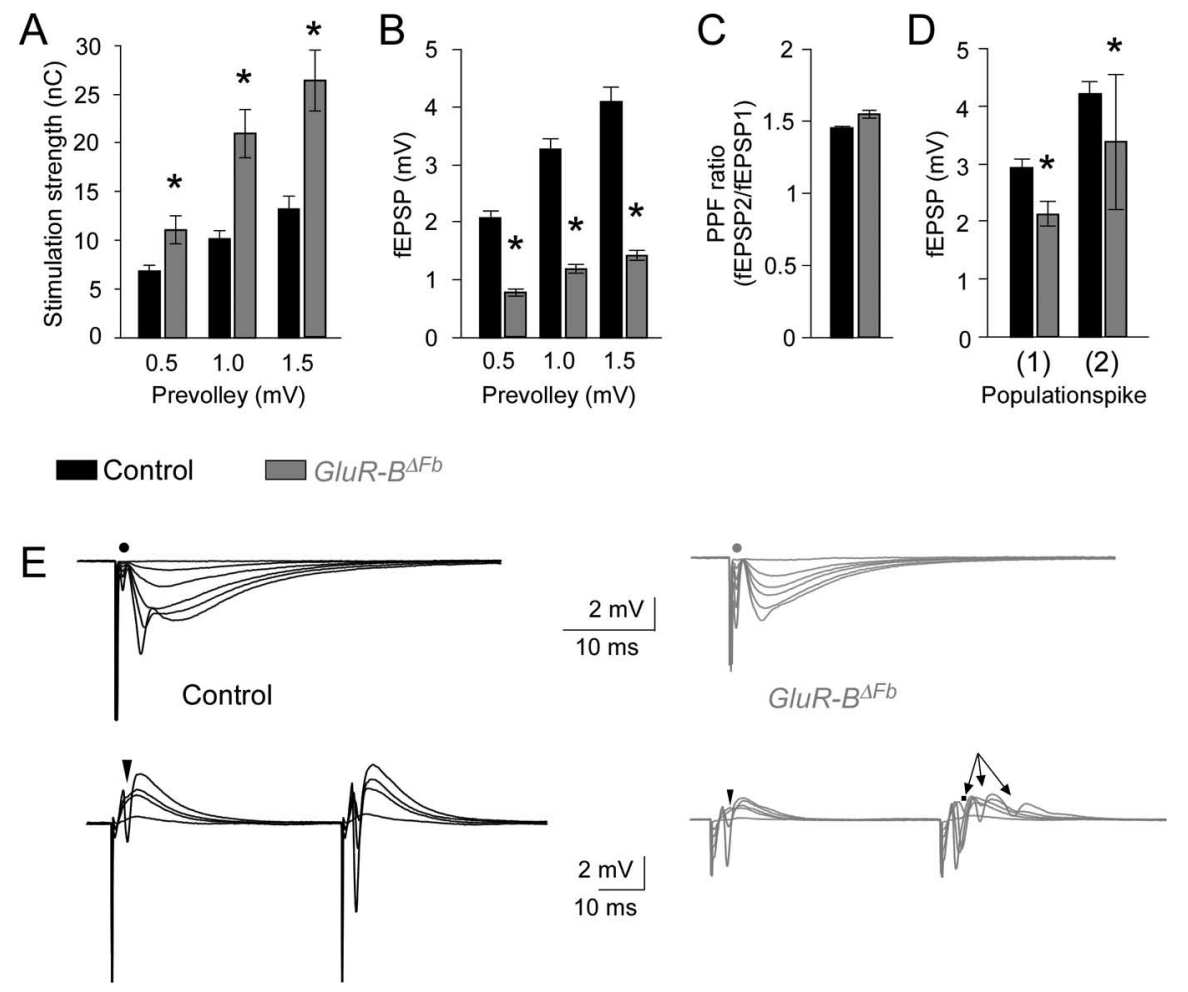

Figure 5. Reduced excitatory transmission but increased synaptic excitability in the hippocampal CA1 region of GluR-B $B^{\Delta F b}$ mice. $A$, Stimulation strengths necessary to elicit a prevolley of a given amplitude $(0.5,1.0$, and $1.5 \mathrm{mV}) . \boldsymbol{B}$, fEPSP amplitudes as a function of the same three prevolley amplitudes. C, Paired-pulse facilitation (PPF) ratio in the two genotypes at an interstimulus interval of $50 \mathrm{~ms}$. D, The fEPSP amplitudes necessary to elicit a just detectable population spike (1) and a population spike of $2 \mathrm{mV}$ amplitude (2). In GluR-B $B^{\Delta F b}$ mice, a population spike was only detectable in 23 of 56 experiments, and in only three experiments did its amplitude exceed $2 \mathrm{mV}$. The number of experiments ranged from 35 to 56 . $\boldsymbol{E}$, Top row, Each trace is the mean of five consecutive synaptic responses in stratum radiatum elicited by different stimulation strengths in slices from control (black) and GluR- $B^{\Delta F b}$ (gray) mice. The prevolleys preceding the fEPSPs are indicated by a filled circle. Bottom row, Recordings from stratum pyramidale elicited by paired-pulse stimulation ( $50 \mathrm{~ms}$ interstimulus interval). Arrowheads indicate the population spike threshold, and triple arrows indicate the appearance of multiple population spikes. Data are shown as mean \pm SEM. Statistical evaluation was done by a Student's two-tailed $t$ test; ${ }^{*} p<0.01$. Control results have, in part, been published previously by Krestel et al. (2004).

GluR-B $B^{\Delta F b}(170 \pm 9 \% ; n=14 ; p<0.05)$ mice. Four repeated tetanizations elicited a more pronounced posttetanic potentiation/short-term potentiation phase in $G l u R-B^{\Delta F b}$ than control mice ( $p<0.05$ for the initial 12 min after tetanization). However, comparison between the genotypes revealed no significant difference in the magnitude of LTP 40-45 min after the tetanizations $(p=0.60)$ (Fig. $6 B, C)$. We followed, in some experiments, the responses for $2 \mathrm{~h}$ to ascertain that the tetanization paradigm applied induced robust and long-lasting LTP. In five experiments in control slices, the fEPSP slopes relative to the pretetanic value were $176 \pm 12 \%$ at $40-45$ min and $180 \pm 27 \%$ at $2 \mathrm{~h}$. Similarly, in six slices from GluR-B$B^{\Delta F b}$ mice, the magnitudes of LTP were $182 \pm 19$ and $167 \pm 14 \%$, respectively. At 2 h posttetanically, we found no significant difference between the two genotypes $(p=0.61)$.

A substantial amount of NMDA receptor-independent LTP was reported in GluR-B-deficient mice (P14-P28) (Jia et al., 1996). However, in our experiments in both control and GluR$B^{\triangle F b}$ slices, LTP was completely blocked in the presence of the NMDA receptor antagonist DL-AP-5 $(50 \mu \mathrm{M})$ [control littermates: tetanized pathway, $103 \pm 4 \%$ vs control pathway, $98 \pm$ $5 \%, n=7, p=0.37$ (Fig. $6 D$ ); GluR- $B^{\Delta F b}$ : tetanized pathway, $100 \pm 3 \%$ vs control pathway, $96 \pm 4 \%, n=12, p=0.42$ (Fig. $6 E)]$. This inconsistency might be attributed to a difference in

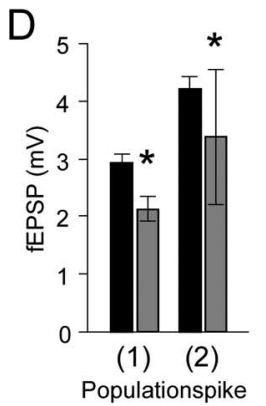

global and forebrain cell-specific GluR-B deletion. However, in hippocampal slices from $G l u R-B$ knock-out mice generated by us, the amount of LTP was not significantly different from that of $G l u R-B^{\Delta F b}$ mice, neither after a single tetanization $(140 \pm 5 \% ; n=23)$ nor after a repeated tetanization procedure $(156 \pm 7 \% ; n=16$; $p=0.83$ and $p=0.24$, respectively) (Fig. $6 C)$. As in the GluR-B $B^{\Delta F b}$ mice, LTP in the GluR-B knock-out mice was further blocked by DL-AP-5 (tetanized pathway, $107 \pm 4 \%$ vs control pathway, $101 \pm 1 \%$; $n=18 ; p=0.07)$. In slices from young (P14) GluR-B knock-out mice, LTP magnitudes after single or repeated tetanizations were similar to those observed in control mice (single tetanization: GluR-B knock-out, $124 \pm 4 \%, n=20$ vs control, $132 \pm 5 \%, n=29, p=0.23$; repeated tetanizations, $155 \pm 6 \%, n=6$ vs control, $158 \pm 9 \%, n=13, p=0.86)$.

Thus, despite the $\mathrm{Ca}^{2+}$ influx through AMPA channels caused by GluR-B ablation in principal neurons, we were unable to detect NMDA receptor-independent field LTP (fLTP).

\section{Impaired spatial working and reference memory in GluR-B $B^{\Delta F b}$ mice}

Although fLTP appeared normal in GluR$B^{\triangle F b}$ mice, the reduced synaptic transmission and increased synaptic excitability suggested that these mice might exhibit learning deficits in hippocampusdependent cognitive tasks. We therefore tested the performance of these mice on the spatial working (T-maze) and spatial reference (Y-maze) tasks, both of which have been shown to depend on intact hippocampus (Deacon et al., 2002; Reisel et al., 2002).

On the T-maze, each trial consists of two runs: a sample run and a choice run. During the sample run, the mouse is directed to one of the two arms; on the subsequent choice run, it is rewarded if it chooses the previously unsampled arm. Mice have a natural tendency to alternate on this task. As expected, the control littermates $(n=10$; older than P60) alternated and increased their success rate (mean \pm SEM, from $70 \pm 5 \%$ on block 1 to $85 \pm 4 \%$ on block 4) within days ( $T=10.997 ; \mathrm{df}=9 ; p<0.001$, paired $t$ test for percentage correct choice in block 1 vs block 4 ) (Fig. 7A; black trace). GluR-B $B^{\Delta F b}$ mice $(n=10)$, however, showed impaired T-maze performance $(F=15.619$; $\mathrm{df}=1 ; p<0.001$, two-way repeated-measures ANOVA) and significantly diminished correct choices on block 3 (difference of means, 20; $T=$ 2.775, $p=0.007$, Holm-Sidak pairwise multiple comparison) and block 4 (difference of means, 34; $T=4.683 ; p<0.001$, Holm-Sidak pairwise multiple comparison). Training on this hippocampal task did not result in learning $(T=1.246 ; \mathrm{df}=9$; $p=0.244$, paired $t$ test for percentage correct choice in block $1 \mathrm{vs}$ block 4) (Fig. 7A, gray trace) after conditional deletion of GluR-B (percentage correct response, block 1, $58 \pm 4 \%$; block 4, $51 \pm$ $4 \%)$. Thus, despite the presence of LTP at CA3-to-CA1 synapses, the spatial working memory was impaired. 
Therefore, we speculated that the primary reason for the loss of hippocampalbased memory formation is the overall changed excitability at hippocampal connections in $G l u R-B^{\Delta F b}$ mice. If this is the case, we should be able to spot the loss of hippocampal function in other hippocampus-dependent memory tasks. We analyzed in detail the spatial reference memory, which is often used as behavioral readout for LTP at CA3-to-CA1 synapses. Spatial reference memory was studied on the Y-maze. In this paradigm, mice were trained to choose a target arm at a constant location with respect to spatial cues in the environment. This task requires animals to use allocentric spatial information to locate the target arm, and hippocampal lesions alter this form of learning (Deacon et al., 2002; Reisel et al., 2002). Control and GluR- $B^{\Delta F b}$ mice ( $n=10$ per group) learned the task, although $G l u R-B^{\Delta F b}$ mice required significantly more trials to reach the asymptotic level of performance $(F=$ 2.426; $\mathrm{df}=11 ; p=0.007$, two-way repeated-measures ANOVA) (Fig. $7 B$, gray trace). Control mice reached the statistically significant level of learning after four blocks of training (percentage correct choice in block 1 compared with block 4 ; difference of means, $1.9 ; T=3.454 ; p=$ 0.01 , Holm-Sidak pairwise multiple comparison) (Fig. 7B, black trace) and continued to perfect their performance thereafter (block 4 vs block 10; difference of means, 2.2; $\mathrm{T}=3.999 ; p<0.001$, Holm-Sidak pairwise multiple comparison). GluR$B^{\triangle F b}$ mice, however, took seven blocks of training to show significant performance enhancement in the task (block 1 vs block 7; difference of means, $2.3 ; T=4.181 ; p<$ 0.001 , Holm-Sidak pairwise multiple comparison). Contrary to the control mice, additional training after learning did not improve the success rate of the $G l u R-B^{\Delta F b}$ mice [block 7 vs block 10; difference of means, $1.1 ; T=2 ; p<0.047$ (not significant according to the $p(0.002)$ corrected for multiple comparison), HolmSidak pairwise multiple comparison].

To estimate at what stage of the training the two groups differed in their performance, we compared the learning curves of the two genotypes (two-way repeated ANOVA for genotype and training blocks). Comparisons across genotypes within training blocks showed that, on blocks $5-8$, control mice performed significantly better than GluR-B $B^{\Delta F b}$ mice (Fig. $\left.7 B\right)(p<0.03$, HolmSidak multiple pairwise). Lack of between-groups difference at the end of the training showed that the asymptotic level of performance was not affected by the GluR-B deletion. This suggested that acquisition, but not maintenance, of the spatial reference memory requires intact hippocampal circuits, which are disturbed weeks after the removal of GluR-B.

After $G l u R-B^{\Delta F b}$ mice had learned the task, we reduced the spatial cues in the environment by placing a wooden mesh curtain around the Y-maze. Such sensory deprivation resulted in impaired performance of $G l u R-B^{\Delta F b}$ (block 10 vs block reduced cues; difference of means, 2.2; $T=3.999 ; p<0.001$, Holm-Sidak
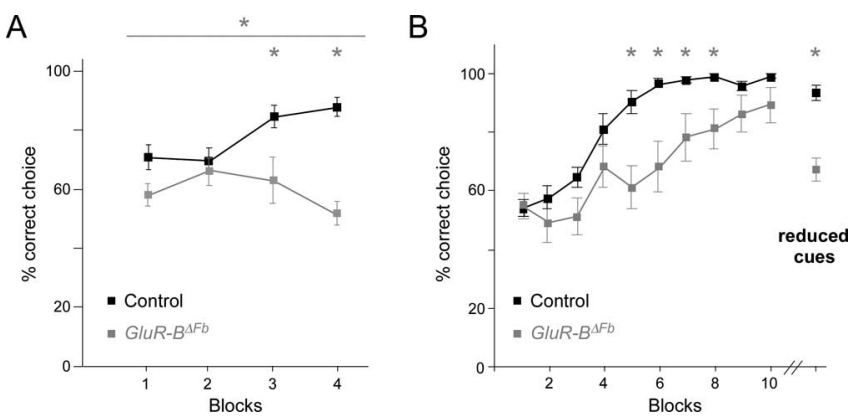

Figure 7. GluR-B $B^{\Delta F b}$ mice show impaired performances in spatial working memory (alternating T-maze) and spatial reference learning (elevated $Y$-maze). $\boldsymbol{A}$, Performance in a nonmatching-to-place alternating T-maze for control (black) and GluR-B ${ }^{\Delta F b}$ (gray) mice. Performance is measured in percentage of correct trials. One block consists of two sessions with four trials each performed in $1 \mathrm{~d}$. $\boldsymbol{B}$, Performance in an elevated $\mathrm{Y}$-maze for control (black) and GluR- $B^{\Delta F b}$ (gray) mice. One block consists of a session of 10 trials performed in $1 \mathrm{~d}$. Data are shown as mean \pm SEM. ${ }^{*} p<0.05$ (in color code) (parts have been published previously by Shimshek et al., 2005).

pairwise multiple comparison) but not of control mice (block 10 vs block reduced cues; difference of means $=0.5 ; T=0.909 ; p<$ 0.364, Holm-Sidak pairwise multiple comparison) compared with the last session of the training. The difference in the percentage correct choice between the two genotypes within the reducedcues session was significant $(T=131.5 ; p<0.001$, Mann-Whit- 
A

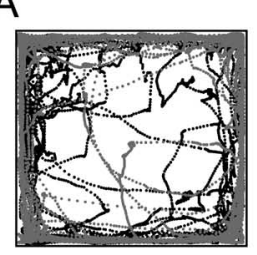

$E$

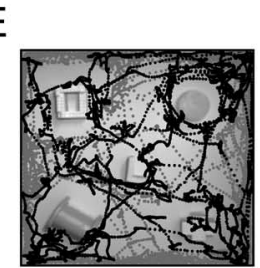

B

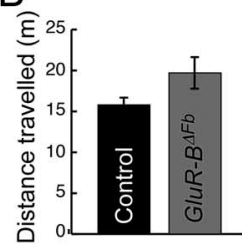

$\mathrm{F}$

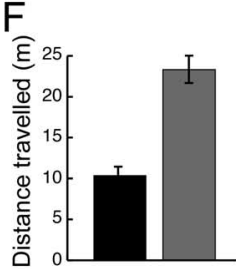

C

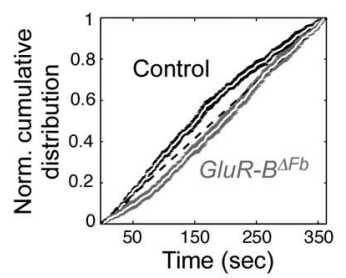

G

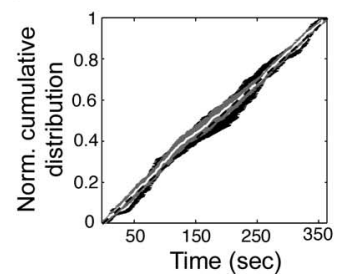

Figure 8. Unimpaired exploratory activity in $G / u R-B^{\Delta F b}$ mice. $A$, Representative examples of open-field exploration (hereafter, black traces, control; gray traces, GluR-B $\left.B^{\Delta F b}\right)$. $B$, Amount of motor exploration of the open-field arena was quantified from the distance traveled during the 6 min session, and it was not significantly altered after the conditional GluR-B depletion (hereafter, black columns, control; gray columns, GluR-B $\left.{ }^{\Delta F b}\right)$. C, Temporal distribution of the exploratory activity in the open field was calculated from the normalized cumulative distribution of the distance traveled. $\boldsymbol{D}$, Spatial distribution of the exploratory activity is represented as the thigmotaxis ratio and did not differ between genotypes. $\boldsymbol{E}-\boldsymbol{H}$, Motor performance of the mice was altered by novel objects in the environment. $\boldsymbol{E}$, Representative examples of exploration after placement of novel objects show that both control (black dots) and GluR-B $B^{\Delta F b}$ (gray dots) explored the novel objects. $F$, Distance traveled within the 6 min session significantly differed between the control and GluR-B ${ }^{\Delta F b}$ mice after placement of novel objects. G, Temporal pattern of exploration was comparable between the two genotypes studied. $\boldsymbol{H}$, Thigmotaxis ratio, a quantification method for spatial pattern of exploration, did not differ between the two groups after novel object placement in the exploration arena. Data are shown as mean \pm SEM.

ney rank sum test) and suggested that the $G l u R-B^{\Delta F b}$ mice required more spatial cues to solve the task.

Together, spatial reference and spatial working memory paradigms indicate that hippocampal circuits function differently after the induced loss of GluR-B-containing AMPA receptors, commensurate with the reduction of excitatory synaptic transmission.

Regular sensorimotor abilities of GluR-B ${ }^{\Delta F b}$ mice

To show that the performance deficit in the T- and Y-maze tasks reflects memory impairments and is not attributable to reduced motor response to sensory stimuli, we studied control $(n=5)$

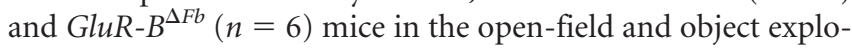
ration paradigms.

Open-field task includes a single session of free exploration in an arena surrounded by walls (Fig. $8 A$ ). Animals were placed into the arena individually for $6 \mathrm{~min}$. Both control and GluR-B$B^{\Delta F b}$ mice explored the environment extensively [Fig. $8 B$ (control, $15.8 \pm 0.8 \mathrm{~m} ; G l u R-B^{\Delta F b}, 19.7 \pm 1.6 \mathrm{~m} ; T=2.141 ; \mathrm{df}=9 ; p=$ $0.061, t$ test)], with similar speed and durations of mobility and immobility (Table $2 A-C$ ). Next the habituation to the environment was quantified by calculating the temporal evolution of mobility. For this, the cumulative distribution of distance normalized to the total distance traveled within the session was analyzed (Fig. 8C). The analysis showed that control mice reached the $50 \%$ level of total exploration significantly earlier than the GluR- $B^{\Delta F b}$ mice $(151 \pm 5$ vs $195 \pm 6 s ; T=5.666 ; \mathrm{df}=9 ; p<$ $0.001, t$ test). However, this difference does not reflect a possible motor impairment but the tendency of GluR-B $B^{\Delta F b}$ mice to explore environment longer because the distance traveled by control $(7.9 \pm 0.4 \mathrm{~m})$ and $G l u R-B^{\Delta F b}(9.9 \pm 0.8 \mathrm{~m})$ mice until they reached $50 \%$ of their total exploration within the session is statistically similar $(T=2.114 ; \mathrm{df}=9 ; p=0.064, t$ test $)$. The difference in the temporal course of habituation between controls and
D

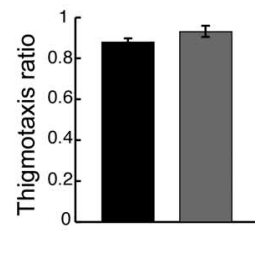

$\mathrm{H}$

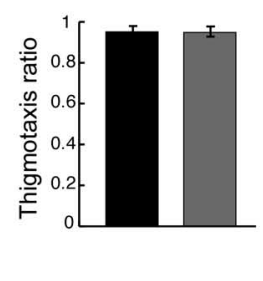

GluR-B $B^{\Delta F b}$ mice did not affect the spatial distribution of the exploration pattern, which was quantified as a ratio between the exploration in the outer half of the arena relative to the inner half (thigmotaxis ratio) (Fig. $8 D$ ). Mice and rats display thigmotaxis as their default exploration mode in novel environments (Luhmann et al., 2005). In agreement with these findings, we found that all of our mice preferentially explored the periphery of the arena (control, $0.951 \pm 0.011 ; G l u R-B^{\Delta F b}$, $0.948 \pm 0.027 ; T=25 ; p=0.429$, MannWhitney rank sum test), and neocortical GluR-B deletion has therefore no affect on the exploratory activity.

The spatial learning deficits after loss of GluR-B might be exaggerated if GluR-B ${ }^{\Delta F b}$ mice fail to notice sensory information available in the environment. To control for such noncognitive parameters, we placed five novel objects in the exploration arena after the open-field task and quantified the motor activity of mice (Fig. $8 E-H$, Table 2). As in the open field, GluR-B $B^{\Delta F b}$ and control mice had comparable motor activity during novel object exploration. Duration of mobility and immobility in the environment were statistically the same (Table 2). Their temporal [Fig. $8 G$ (control, $188 \pm 12 \mathrm{~s}$; GluR- $B^{\Delta F b}, 178 \pm 12$ s to latency to $50 \%$ of total exploration; $T=$ $-0.486 ; \mathrm{df}=9 ; p=0.638, t$ test $)]$ and spatial thigmotaxis patterns [Fig. $8 H$ (control, $0.88 \pm 0.06$; GluR- $B^{\Delta F b}, 0.93 \pm 0.02 ; T=$ $0.803 ; \mathrm{df}=9 ; p=0.443, t$ test $)]$ of exploration were indistinguishable from each other. However, total distance traveled during the session differed between the GluR-B $B^{\Delta F b}$ and control mice [Fig. $8 F$ (control, $10.3 \pm 1.0 \mathrm{~m}$; GluR-B $B^{\Delta F b}, 23 \pm 1.5 \mathrm{~m} ; T=$ $6.970 ; \mathrm{df}=9 ; p<0.001, t$ test $)]$, indicating increased exploration by $G l u R-B^{\Delta F b}$ mice after introduction of novel objects.

These results show that sensorimotor abilities of GluR-B $B^{\Delta F b}$ mice are comparable with those of control mice, and the cognitive deficits described in hippocampus-dependent spatial tasks are not confounded by the noncognitive factors tested, such as lack of motor activity or exploration of sensory information.

\section{Discussion}

We have, in mice, investigated long-term changes in the hippocampal formation caused by conditional deletion of GluR-B subunits in principal forebrain neurons. The conditional model allowed us to circumvent developmental effects of GluR-B absence, which may occur in GluR-B knock-out mice.

As long term changes, we found reduction in the number of CA3 pyramidal cells, a moderate reduction in hippocampal interneuron populations, and lack of hippocampal neurogenesis. Excitatory synaptic transmission was severely reduced relative to controls in the CA1 region, but the threshold for eliciting a population spike was lower, indicating increased synaptic excitability after GluR-B removal. The underlying molecular mechanism for the enhanced excitability in $G l u R-B^{\Delta F b}$ mice is not resolved. We speculate whether the $\mathrm{Ca}^{2+}$ influx through AMPA receptors in excitatory neurons of $G l u R-B^{\Delta F b}$ mice is the primary cause for the long-term changes in excitability of the hippocampal network, because we see very similar changes in GluR-B $B^{Q F b}$ mice. Like 
Table 2. Statistics of motor activity

\begin{tabular}{|c|c|c|c|c|c|c|c|}
\hline & \multicolumn{3}{|c|}{$A$, Distribution of speed $(\mathrm{cm} / \mathrm{s})$} & \multicolumn{2}{|c|}{$B$, Duration of mobility (s) } & \multicolumn{2}{|c|}{ C, Duration of immobility (s) } \\
\hline & $25 \%$ & $50 \%$ (median) & $75 \%$ & - objects & + objects & - objects & + objects \\
\hline Control & $0.34(0.24-0.42)$ & $1.63(1.23-1.79)$ & $5.83(5.33-6.68)$ & 335 (317-338) & $351(346-352)$ & $30(24-39)$ & $8(8-15)$ \\
\hline GluR-B $B^{\Delta F b}$ & $0.35(0.29-0.37)$ & $1.48(1.26-1.81)$ & $7.06(5.54-9.81)$ & $329(320-335)$ & $337(331-341)$ & $24(21-43)$ & $24(18-28)$ \\
\hline
\end{tabular}

$A$, Distribution of speed. The range of speed at which animals moved in the open field is described by the median (50\%) and the interquartile range (25\%-75\%) of the speed distribution. $B$, C, Duration of mobility and immobility. Mobility measurements based on distance traveled within a certain time epoch might be confounded by the speed of movement. Therefore, we quantified the duration of mobility and immobility with or without novel objects present in the environment. None of the values presented in the table significantly differed from each other across both groups of mice. All values are median and interquartile range (in parentheses).

GluR- $B^{\Delta F b}, G l u R-B^{Q F b}$ mice have $\mathrm{Ca}^{2+}$-permeable AMPA receptors in principal neurons of the forebrain. However, the reduction in AMPA receptor-mediated transmission is not as pronounced as in GluR-B $B^{\Delta F b}$ mice, and the enhanced excitability in GluR-B $B^{Q F b}$ mice may lead to mild and rare (approximately every $4 \mathrm{~d})$ epileptic activity with seizure attacks that can generalize (Krestel et al., 2004).

Most of the observed changes appear to be secondary in nature and are not directly coupled to changes in AMPA receptor signaling of principal neurons. This becomes especially evident from alterations in neuronal populations, which do express little or no GluR-B at all, such as GABAergic interneurons and neuronal stem cells in the subgranular zone of the hippocampus. Similarly, the loss of CA3 pyramidal neurons in GluR-B ${ }^{\Delta F b}$ mice was not observed in GluR-B $B^{Q F b}$ mice and might therefore not be directly caused by $\mathrm{Ca}^{2+}$-induced neurodegeneration, as predicted by a popular hypothesis (Friedman, 1998; Friedman and Koudinov, 1999; Oguro et al., 1999; Grooms et al., 2000; Tanaka et al., 2000). This view is supported by recent experiments, in which transient expression of $\mathrm{Ca}^{2+}$-permeable AMPA receptors fails to induce cell death in pyramidal neurons (Oguro et al., 1999; Anzai et al., 2003; Liu et al., 2004). The reduced number of CA3 pyramidal cells in GluR-B ${ }^{\Delta F b}$ mice might compensate for the recurrent excitation by the observed mossy fiber sprouting of granule cells in DG, thus preventing epileptiform hippocampal discharges. The best evidence for reduced hippocampal activity comes from the lack of neurogenesis in the subgranular zone in GluR-B $B^{\Delta F b}$ mice. Neurogenesis is enhanced by stimulation of the perforant path (Parent et al., 1997), in rodents by pharmacologically induced epilepsy (Parent et al., 1997; Scharfman et al., 2000 ) and in epileptic GluR-B $B^{Q F b}$ mice. In $G l u R-B^{\Delta F b}$ mice, which lack an epileptic phenotype, neurogenesis in DG was suppressed. Thus, the activity of hippocampal circuits seems to be reduced in GluR-B $B^{\Delta F b}$ mice, which furthermore correlates with a reduced number of CA3 pyramidal cells and a reduced prevolley amplitude in CA1.

In addition, as indicated by a reduced fEPSP elicited by a given prevolley size, the excitatory synaptic transmission at CA3-toCA1 synapses was severely impaired. This conclusion is supported also by the fact that in only $40 \%$ of the experiments were we able to stimulate with sufficient strength to elicit a population spike. The reduced AMPA-mediated transmission is most likely caused by a decreased number of synapses and/or reduced presence of synaptic AMPA receptors, because paired-pulse facilitation was unaltered. The impairment in transmission must have a profound functional impact on hippocampal information flow and processing.

Both the paired-pulse facilitation ratio and the amount of NMDA-dependent LTP, however, were unchanged, suggesting that the underlying mechanisms for these forms of synaptic plasticity remained intact. These findings furthermore suggest that the remaining GluR-A containing AMPA receptors are sufficient for these forms of plasticity at CA3-to-CA1 synapses and are consistent with in vitro data showing that activation of GluR-A homomeric receptors can induce LTP (Shi et al., 1999; Meng et al., 2003).

Our LTP findings do not substantiate the twofold increase in LTP and the considerable amount of NMDA receptorindependent LTP reported previously in young GluR-B knockout mice at CA3-to-CA1 synapses (Jia et al., 1996). LTP in our experiments, both after a single and a four times tetanization paradigm, was not significantly different from LTP obtained in control mice, in neither $G l u R-B^{\Delta F b}$ nor adult or young $G l u R-B$ knock-out mice. In addition, LTP was completely blocked by a four times lower concentration of DL-AP-5 than the one used by Jia et al. (1996). Although there were minor differences in recording conditions, such as the concentration of extracellular $\mathrm{Ca}^{2+}$ and the induction protocols for LTP, these can hardly explain the quantitative and qualitative differences in LTP. We cannot, in an obvious manner, explain the discrepancies between the two studies. We were unable to elicit an NMDA receptor-independent LTP in the CA3-to-CA1 synapses in our conditional mouse mutants. This suggests that the transient synaptic $\mathrm{Ca}^{2+}$ influx through GluR-B lacking AMPA receptors (Krestel et al., 2004) is insufficient and/or additional highly localized signaling mechanisms are necessary to induce LTP.

Despite normal LTP, GluR-B $B^{\Delta F b}$ mice were impaired in a hippocampus-dependent spatial working memory (T-maze) task. Previously, we have shown that learning performance in the T-maze task is correlated with GluR-A-dependent LTP (Mack et al., 2001; Reisel et al., 2002). Therefore, in GluR- $B^{\Delta F b}$ mice, the impaired performance in the T-maze can best be ascribed to severely reduced excitatory transmission in hippocampal connections. Results from the hippocampus-dependent spatial reference memory task (elevated Y-maze) supported this view. Learning this task is GluR-A independent and not correlated with GluR-A-dependent LTP (Reisel et al., 2002). Although GluR$B^{\triangle F b}$ mice ultimately learned the task, they showed a slower acquisition phase than control littermates. Thus, the spatial reference memory was intact, but the reduced transmission in hippocampal circuits most probably impaired the task acquisition. Similarly, reduction in spatial cues after learning impaired their performance. This might represent impairment in pattern completion, most likely caused by a reduced number of CA3 pyramidal cells (Nakazawa et al., 2002) (for review, see Guzowski et al., 2004). The cognitive deficits described in hippocampusdependent spatial tasks are not confounded by the noncognitive impairments, which might have been induced after forebrainspecific GluR-B removal. GluR-B $B^{\Delta F b}$ mice have normal sensorimotor abilities in the open-field test, show interest in novel objects, and have the tendency to explore the environment more extensively then control mice.

In summary, several weeks after the genetically induced postnatal depletion of the GluR-B subunit in forebrain principal neurons, we detected a modest increase of mossy fiber sprouting and a reduction in the number of CA3 pyramidal and DG 
parvalbumin-expressing neurons. These cellular changes were accompanied by reduced levels of hippocampal activity, as evidenced by a near complete loss of neurogenesis in the subgranular zone. Despite the drastic changes in excitatory synaptic transmission and excitability in the CA1 region, we were unable to unmask changes in paired-pulse facilitation and LTP. In the absence of sensory or motor deficiencies of GluR-B $B^{\Delta F b}$ mice, the hippocampus-specific memory and learning tests revealed impaired spatial working memory and slow acquisition of spatial reference memory. Both learning and memory deficits most likely are signs of a severe reduction in fast hippocampal excitatory transmission after the loss of GluR-B.

\section{References}

Andrásfalvy BK, Smith MA, Borchardt T, Sprengel R, Magee JC (2003) Impaired regulation of synaptic strength in hippocampal neurons from GluR1-deficient mice. J Physiol (Lond) 552:35-45.

Anzai T, Tsuzuki K, Yamada N, Hayashi T, Iwakuma M, Inada K, Kameyama K, Hoka S, Saji M (2003) Overexpression of $\mathrm{Ca}^{2+}$-permeable AMPA receptor promotes delayed cell death of hippocampal CA1 neurons following transient forebrain ischemia. Neurosci Res 46:41-51.

Bannerman DM, Deacon RM, Brady S, Bruce A, Sprengel R, Seeburg PH, Rawlins JN (2004) A comparison of GluR-A-deficient and wild-type mice on a test battery assessing sensorimotor, affective, and cognitive behaviors. Behav Neurosci 118:643-647.

Borchardt T (2002) Die Konstruktion von Mäusen mit veränderten AMPARezeptoren. $\mathrm{PhD}$ thesis, Ruprecht-Karls-Universitaet.

Brusa R, Zimmermann F, Koh DS, Feldmeyer D, Gass P, Seeburg PH, Sprengel R (1995) Early-onset epilepsy and postnatal lethality associated with an editing-deficient GluR-B allele in mice. Science 270:1677-1680.

Danscher G (1982) Exogenous selenium in the brain. A histochemical technique for light and electron microscopical localization of catalytic selenium bonds. Histochemistry 76:281-293.

Deacon RM, Bannerman DM, Kirby BP, Croucher A, Rawlins JN (2002) Effects of cytotoxic hippocampal lesions in mice on a cognitive test battery. Behav Brain Res 133:57-68.

Engelman HS, Allen TB, MacDermott AB (1999) The distribution of neurons expressing calcium-permeable AMPA receptors in the superficial laminae of the spinal cord dorsal horn. J Neurosci 19:2081-2089.

Friedman LK (1998) Selective reduction of GluR2 protein in adult hippocampal CA3 neurons following status epilepticus but prior to cell loss. Hippocampus 8:511-525.

Friedman LK, Koudinov AR (1999) Unilateral GluR2(B) hippocampal knockdown: a novel partial seizure model in the developing rat. J Neurosci 19:9412-9425.

Gagneten S, Le Y, Miller J, Sauer B (1997) Brief expression of a GFP cre fusion gene in embryonic stem cells allows rapid retrieval of site-specific genomic deletions. Nucleic Acids Res 25:3326-3331.

Grooms SY, Opitz T, Bennett MV, Zukin RS (2000) Status epilepticus decreases glutamate receptor $2 \mathrm{mRNA}$ and protein expression in hippocampal pyramidal cells before neuronal death. Proc Natl Acad Sci USA 97:3631-3636.

Guzowski JF, Knierim JJ, Moser EI (2004) Ensemble dynamics of hippocampal regions CA3 and CA1. Neuron 44:581-584.

He Y, Janssen WG, Vissavajjhala P, Morrison JH (1998) Synaptic distribution of GluR2 in hippocampal GABAergic interneurons and pyramidal cells: a double-label immunogold analysis. Exp Neurol 150:1-13.

Jia Z, Agopyan N, Miu P, Xiong Z, Henderson J, Gerlai R, Taverna FA, Velumian A, MacDonald J, Carlen P, Abramow-Newerly W, Roder J (1996) Enhanced LTP in mice deficient in the AMPA receptor GluR2. Neuron 17:945-956.

Jia Z, Lu YM, Agopyan N, Roder J (2001) Gene targeting reveals a role for the glutamate receptors mGluR5 and GluR2 in learning and memory. Physiol Behav 73:793-802.

Kask K, Zamanillo D, Rozov A, Burnashev N, Sprengel R, Seeburg PH (1998) The AMPA receptor subunit GluR-B in its Q/R site-unedited form is not essential for brain development and function. Proc Natl Acad Sci USA 95:13777-13782.

Keinanen K, Wisden W, Sommer B, Werner P, Herb A, Verdoorn TA, Sakmann B, Seeburg PH (1990) A family of AMPA-selective glutamate receptors. Science 249:556-560.
Kempermann G, Kuhn HG, Gage FH (1997a) More hippocampal neurons in adult mice living in an enriched environment. Nature 386:493-495.

Kempermann G, Kuhn HG, Gage FH (1997b) Genetic influence on neurogenesis in the dentate gyrus of adult mice. Proc Natl Acad Sci USA 94:10409-10414.

Krestel HE, Shimshek DR, Jensen V, Nevian T, Kim J, Geng Y, Bast T, Depaulis A, Schonig K, Schwenk F, Bujard H, Hvalby O, Sprengel R, Seeburg PH (2004) A genetic switch for epilepsy in adult mice. J Neurosci 24:10568-10578.

Leranth C, Szeidemann Z, Hsu M, Buzsaki G (1996) AMPA receptors in the rat and primate hippocampus: a possible absence of GluR2/3 subunits in most interneurons. Neuroscience 70:631-652.

Liu S, Lau L, Wei J, Zhu D, Zou S, Sun HS, Fu Y, Liu F, Lu Y (2004) Expression of $\mathrm{Ca}^{2+}$-permeable AMPA receptor channels primes cell death in transient forebrain ischemia. Neuron 43:43-55.

Luhmann HJ, Huston JP, Hasenohrl RU (2005) Contralateral increase in thigmotactic scanning following unilateral barrel-cortex lesion in mice. Behav Brain Res 157:39-43.

Mack V, Burnashev N, Kaiser KM, Rozov A, Jensen V, Hvalby O, Seeburg PH, Sakmann B, Sprengel R (2001) Conditional restoration of hippocampal synaptic potentiation in Glur-A-deficient mice. Science 292:2501-2504.

Mantamadiotis T, Lemberger T, Bleckmann SC, Kern H, Kretz O, Martin Villalba A, Tronche F, Kellendonk C, Gau D, Kapfhammer J, Otto C, Schmid W, Schutz G (2002) Disruption of CREB function in brain leads to neurodegeneration. Nat Genet 31:47-54.

Meng Y, Zhang Y, Jia Z (2003) Synaptic transmission and plasticity in the absence of AMPA glutamate receptor GluR2 and GluR3. Neuron 39:163-176.

Moga D, Hof PR, Vissavajjhala P, Moran TM, Morrison JH (2002) Parvalbumin-containing interneurons in rat hippocampus have an AMPA receptor profile suggestive of vulnerability to excitotoxicity. J Chem Neuroanat 23:249-253.

Morimoto K, Fahnestock M, Racine RJ (2004) Kindling and status epilepticus models of epilepsy: rewiring the brain. Prog Neurobiol 73:1-60.

Nagy A, Rossant J, Nagy R, Abramow-Newerly W, Roder JC (1993) Derivation of completely cell culture-derived mice from early-passage embryonic stem cells. Proc Natl Acad Sci USA 90:8424-8428.

Nakazawa K, Quirk MC, Chitwood RA, Watanabe M, Yeckel MF, Sun LD, Kato A, Carr CA, Johnston D, Wilson MA, Tonegawa S (2002) Requirement for hippocampal CA3 NMDA receptors in associative memory recall. Science 297:211-218.

Oguro K, Oguro N, Kojima T, Grooms SY, Calderone A, Zheng X, Bennett MV, Zukin RS (1999) Knockdown of AMPA receptor GluR2 expression causes delayed neurodegeneration and increases damage by sublethal ischemia in hippocampal CA1 and CA3 neurons. J Neurosci 19:9218-9227.

Parent JM, Yu TW, Leibowitz RT, Geschwind DH, Sloviter RS, Lowenstein DH (1997) Dentate granule cell neurogenesis is increased by seizures and contributes to aberrant network reorganization in the adult rat hippocampus. J Neurosci 17:3727-3738.

Pollard H, Heron A, Moreau J, Ben-Ari Y, Khrestchatisky M (1993) Alterations of the GluR-B AMPA receptor subunit flip/flop expression in kainate-induced epilepsy and ischemia. Neuroscience 57:545-554.

Reisel D, Bannerman DM, Schmitt WB, Deacon RM, Flint J, Borchardt T, Seeburg PH, Rawlins JN (2002) Spatial memory dissociations in mice lacking GluR1. Nat Neurosci 5:868-873.

Sanchis-Segura C, Borchardt T, Vengeliene V, Zghoul T, Bachteler D, Gass P, Sprengel R, Spanagel R (2006) Involvement of the AMPA receptor GluR-C subunit in alcohol-seeking behavior and relapse. J Neurosci 26:1231-1238.

Sans N, Vissel B, Petralia RS, Wang YX, Chang K, Royle GA, Wang CY, O'Gorman S, Heinemann SF, Wenthold RJ (2003) Aberrant formation of glutamate receptor complexes in hippocampal neurons of mice lacking the GluR2 AMPA receptor subunit. J Neurosci 23:9367-9373.

Scharfman HE, Goodman JH, Sollas AL (2000) Granule-like neurons at the hilar/CA3 border after status epilepticus and their synchrony with area CA3 pyramidal cells: functional implications of seizure-induced neurogenesis. J Neurosci 20:6144-6158.

Schwenk F, Baron U, Rajewsky K (1995) A cre-transgenic mouse strain for the ubiquitous deletion of loxP-flanked gene segments including deletion in germ cells. Nucleic Acids Res 23:5080-5081.

Shi S, Hayashi Y, Esteban JA, Malinow R (2001) Subunit-specific rules gov- 
erning AMPA receptor trafficking to synapses in hippocampal pyramidal neurons. Cell 105:331-343.

Shi SH, Hayashi Y, Petralia RS, Zaman SH, Wenthold RJ, Svoboda K, Malinow R (1999) Rapid spine delivery and redistribution of AMPA receptors after synaptic NMDA receptor activation. Science 284:1811-1816.

Shimshek DR, Kim J, Hubner MR, Spergel DJ, Buchholz F, Casanova E, Stewart AF, Seeburg PH, Sprengel R (2002) Codon-improved Cre recombinase (iCre) expression in the mouse. Genesis 32:19-26.

Shimshek DR, Bus T, Kim J, Mihaljevic A, Mack V, Seeburg PH, Sprengel R, Schaefer AT (2005) Enhanced odor discrimination and impaired olfactory memory by spatially controlled switch of AMPA receptors. PLoS Biol 3:e354.

Shimshek DR, Bus T, Grinevich V, Single FN, Mack V, Sprengel R, Spergel DJ, Seeburg PH (2006) Impaired reproductive behavior by lack of GluR-B containing AMPA receptors but not of NMDA receptors in hypothalamic and septal neurons. Mol Endocrinol 20:219-231.

Steward O (1994) Electroconvulsive seizures upregulate astroglial gene ex- pression selectively in the dentate gyrus. Brain Res Mol Brain Res 25:217-224.

Stringer JL (1996) Repeated seizures increase GFAP and vimentin in the hippocampus. Brain Res 717:147-153.

Tanaka H, Grooms SY, Bennett MV, Zukin RS (2000) The AMPAR subunit GluR2: still front and center-stage. Brain Res 886:190-207.

Washburn MS, Dingledine R (1996) Block of alpha-amino-3-hydroxy-5methyl-4-isoxazolepropionic acid (AMPA) receptors by polyamines and polyamine toxins. J Pharmacol Exp Ther 278:669-678.

Wenthold RJ, Petralia RS, Blahos II J, Niedzielski AS (1996) Evidence for multiple AMPA receptor complexes in hippocampal CA1/CA2 neurons. J Neurosci 16:1982-1989.

Zamanillo D, Sprengel R, Hvalby O, Jensen V, Burnashev N, Rozov A, Kaiser KM, Koster HJ, Borchardt T, Worley P, Lubke J, Frotscher M, Kelly PH, Sommer B, Andersen P, Seeburg PH, Sakmann B (1999) Importance of AMPA receptors for hippocampal synaptic plasticity but not for spatial learning. Science 284:1805-1811. 